\title{
Phylogenetic relationships of the enigmatic Carlastyanax aurocaudatus (Eigenmann) with remarks on the phylogeny of the Stevardiinae (Teleostei: Characidae)
}

\author{
Juan Marcos Mirande ${ }^{1}$, Fernando Camargo Jerep² and James Anyelo Vanegas-Ríos ${ }^{3}$
}

\begin{abstract}
The monotypic genus Carlastyanax Géry was defined to include Astyanax aurocaudatus, a morphologically odd species having, among other features, four teeth in the posterior premaxillary row and eight branched dorsal-fin rays. Later on, the characters used to define Carlastyanax were considered as invalid and this genus was synonymized with Astyanax. In this paper, we include Astyanax aurocaudatus in a phylogeny of the Characidae and obtain a sister-group relationship between this species and Creagrutus, within the Stevardiinae. The resurrection of Carlastyanax as a valid genus is therefore proposed. The analysis presented is the largest phylogeny of the Stevardiinae so far published. Relationships of this subfamily are also discussed.
\end{abstract}

El género monotípico Carlastyanax Géry fue definido para incluir a Astyanax aurocaudatus, una especie morfológicamente extraña que tiene, entre otras cosas, cuatro dientes en la fila posterior del premaxilar y ocho radios ramificados en la aleta dorsal. Luego, los caracteres usados para definir Carlastyanax fueron considerados inválidos y este género fue sinonimizado con Astyanax. En este artículo incluimos Astyanax aurocaudatus en una filogenia de Characidae y obtenemos una relación de grupos hermanos entre esta especie y Creagrutus, dentro de Stevardiinae. La resurrección de Carlastyanax como un género válido es aquí propuesta. Este análisis es la filogenia más grande de Stevardiinae publicada hasta el momento. Se discuten también las relaciones de esta subfamilia.

Key words: Creagrutus, Morphology, Ostariophysi, Osteology, Systematics.

\section{Introduction}

The Stevardiinae is one of the most diverse subfamilies of Characidae, with more than 200 described species. This subfamily comprises the genera included in the "clade A" of Malabarba \& Weitzman (2003), defined by having the combination of eight branched dorsal-fin rays and four teeth on the posterior premaxillary row [including the genera traditionally grouped into the Glandulocaudinae by sharing a secondary sexual caudal-fin gland (Eigenmann, 1914; Géry, 1977; Weitzman \& Menezes, 1998)] and Aulixidens Böhlke, Bryconadenos Weitzman, Menezes, Evers \& Burns, Lepidocharax Ferreira, Menezes \& Quagio-Grassioto, Nantis Mirande, Aguilera \& Azpelicueta, and Phallobrycon Menezes, Ferreira \& Netto-Ferreira (Mirande, 2010; Ferreira et al. 2011). The monophyly of a clade assignable to the Stevardiinae was obtained in all the phylogenies of the Characidae published, both from molecules [Calcagnotto et al., 2005 (six species); Javonillo et al., 2010 (32 species); Oliveira et al., 2011 (21 or 23 species depending on the inclusion or not of Bryconamericus emperador (Eigenmann \& Ogle) and Markiana nigripinnis (Perugia) in the Stevardiinae)] and morphology [Mirande, 2009, 2010 (26 species)]. The internal relationships of the Stevardiinae are, on the other hand, much variable among the different published analyses.

The monotypic genus Carlastyanax Géry was created to include Astyanax aurocaudatus Eigenmann (Géry, 1972) (Fig. 1). This species was described in Astyanax by Eigenmann (1913), in spite of the presence of four teeth in the posterior premaxillary row ( $v s$. five in Astyanax). Several diagnostic morphological features, especially the presence of a hooked third dentary tooth, were used by Géry (1972) to justify the creation of Carlastyanax, although some of these features are either present in many species of the Characidae, or are easily

${ }^{1}$ CONICET-Fundación Miguel Lillo, Miguel Lillo 251, 4000 San Miguel de Tucumán, Argentina. mcmirande@gmail.com

${ }^{2}$ Division of Fishes, Department of Vertebrate Zoology, National Museum of Natural History, Smithsonian Institution, Washington, D.C. 20013-7012.fjerep@gmail.com

${ }^{3}$ CONICET, División Zoología de Vertebrados, Facultad de Ciencias Naturales y Museo, Paseo del Bosque S/N, B1900FWA La Plata, Buenos Aires, Argentina. anyelovr@fcnym.unlp.edu.ar 
explainable as autapomorphies. According to Géry (1972), the characters diagnosing Carlastyanax are: (1) two rows of premaxillary teeth, with anterior row bearing 4-5 tricuspid teeth and posterior row bearing 4 , rarely 5 , tri- to pentacuspid teeth; (2) anterior nostril tubuliform; (3) branchiostegal membrane not fused to the isthmus, but on its counterpart across the isthmus; (4) gill rakers few, short, and rounded or lanceolate; (5) reduction of the infraorbitals 1,5 , and 6 ; (6) dorsal fin equidistant between the snout and the end of the hypural; (7) adipose fin present; (8) caudal fin not covered by scales; (9) pelvic fin (i)i, 5 rays; and (10) lateral line almost completely pored, except for the last one to three scales (Géry, 1972).

Román Valencia \& Ruiz-C. (2005) and Ruiz-C. \& RománValencia (2006) synonymized Carlastyanax with Astyanax based on the variable form of the hooked third dentary tooth in Carlastyanax, which they compared with variations in the form of this tooth in species of Astyanax, and by the inconsistency, in their opinion, of some additional data presented by Géry (1972) to diagnose Carlastyanax. Ruiz-C. \& Román Valencia (2006) cited Bertaco \& Malabarba (2001) as providing information on some species of Astyanax with a hooked third dentary tooth, but all dentaries illustrated in their paper have regular posteriorly curved teeth. Furthermore, and more important than the discussion of that character as diagnostic for Carlastyanax, Ruiz-C. \& Román-Valencia (2006) synonymized Carlastyanax with Astyanax without considering two issues when a phylogeny is not available to support taxonomic decisions: does Carlastyanax aurocaudatus have the character combination defining a species of Astyanax, or does Carlastyanax aurocaudatus have a character combination suggesting a relationship with a particular group within the Characidae?

Both questions had answers at that time. Carlastyanax aurocaudatus has only four teeth on the posterior premaxillary row ( $v s$. five in Astyanax) and eight branched dorsal-fin rays (vs. nine in most species of Astyanax). Those two features exclude Carlastyanax from Astyanax, regardless of the validity of a hooked third dentary tooth as a "generic" character. However, a relatively well-corroborated phylogenetic analysis of the Characidae was not available when Ruiz-C. \& Román-Valencia (2006) synonymized those two genera. Knowledge about characid phylogeny has been much improved in the last years (Mirande, 2009, 2010; Mirande et al., 2011), which allow us to test if that synonymy is justifiable, and also to propose a more precise hypothesis about the relationships of Carlastyanax.

The goal of this paper is to elucidate the phylogenetic relationships of Carlastyanax in a familial context, especially to test if this genus is valid and if it is related to Astyanax and/or to the Stevardiinae. We also present the most comprehensive phylogeny of the Stevardiinae to date, with 41 species examined and coded for the phylogenetic characters of Mirande (2010) plus 51 species of Creagrutus Günther that were not examined, but coded from observations of Vari \& Harold (2001) and Torres-Mejia \& Vari (2005).

\section{Material and Methods}

Two datasets were analyzed. In the first one, which we refer to as Examined Matrix, 17 species were added to the matrix of Mirande $(2009,2010)$ and Mirande et al. (2011). First approximations to the analysis herein presented suggested that Carlastyanax was closely related to Creagrutus. In order to test more adequately the relationships between these two genera, a second dataset based on the Examined Matrix, with the addition of 51 species of Creagrutus coded exclusively from literature (Vari \& Harold, 2001; Torres-Mejia \& Vari, 2005),

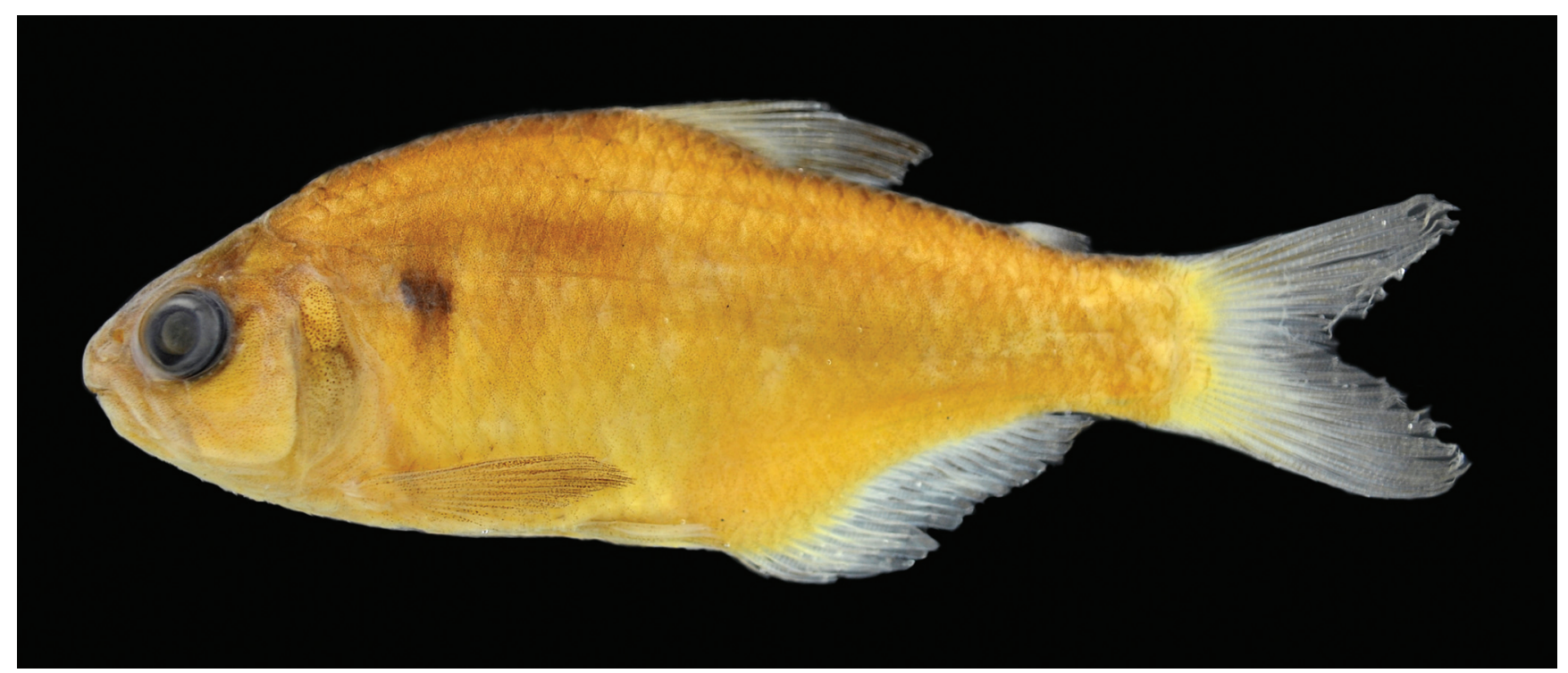

Fig. 1. Carlastyanax aurocaudatus, CI-FML 5015, $46.2 \mathrm{~mm}$ SL. Alcohol-preserved specimen. 
was generated. This second dataset is herein referred to as the Extended Matrix.

The species added to the Examined Matrix are: Argopleura magdalenensis (Eigenmann), Bryconadenos tanaothoros Weitzman, Menezes, Evers \& Burns, Carlastyanax aurocaudatus, Creagrutus atrisignum Myers, C. cracentis Vari \& Harold, C. gephyrus Böhlke \& Saul, C. maracaiboensis (Schultz), C. meridionalis Vari \& Harold, C. muelleri (Günther), C. ouranonastes Vari \& Harold, C. peruanus (Steindachner), Hyphessobrycon megalopterus (Eigenmann), Knodus heteresthes (Eigenmann), K. meridae Eigenmann, K. pectinatus (Vari \& Siebert), Microgenys minuta Eigenmann, and Piabarchus analis (Eigenmann). Most of those species were selected to improve the sampling within the Stevardiinae. Also, Knodus pectinatus and Microgenys minuta are morphologically similar to Carlastyanax (Vari \& Siebert, 1990; pers. obs.), and therefore those species were included in the analysis to test if Carlastyanax was related to them. The recently described fossil characids Paleotetra aiuruoca Weiss, Malabarba \& Malabarba and P. entrecorregos Weiss, Malabarba \& Malabarba were also added to this analysis based on the observations published by Weiss et al. (2012), where the authors coded these species for the characters proposed by Mirande (2010). The populations of Nantis analyzed as different terminal taxa by Mirande (2009, 2010) were merged in Nantis indefessus Mirande, Aguilera \& Azpelicueta based in further comparisons (Mirande, 2012). The terminal taxa named as Bryconamericus exodon Eigenmann and $B$. cf. exodon by Mirande $(2009,2010)$ were merged as $B$. exodon. The specimens coded by Mirande $(2009,2010)$ as Diapoma terofali (Géry) are actually specimens of the recently described Cyanocharax obi Casciotta, Almirón, Piálek \& Øíncan (Casciotta et al., 2012). The specimens cited as Hyphessobrycon luetkenii by Mirande (2010) were found to be $H$. meridionalis and are herein named accordingly. With those additions and modifications, the Examined Matrix has 182 terminals (species), whereas the Extended Matrix has 233 species.

Characters analyzed are those from Mirande (2010) with the addition of one character from Mirande et al. (2011) and 26 characters mostly from Vari \& Harold (2001), which are listed below. Although some of these characters are at present uninformative, they were maintained in the analysis considering future potential addition of terminals. A total of 392 characters were analyzed. All phylogenetic analyses were performed with TNT (Goloboff et al., 2008a) under implied weighting (Goloboff, $1993)$ following the criteria by Mirande $(2009,2010)$. The implied weighting method takes into account the congruence between characters during tree searches. As the phylogeny is judged to be the most important source of correlation between characters, those characters that are more congruent to each other are also supposed to be the most correlated with the phylogeny, and therefore more weight is attributable to them during searches. This method has a constant $\mathrm{K}$ that permit to adjust how much the characters are down-weighted in relation to their homoplasy. As equal weighting is equivalent to using a value of $\mathrm{K}$ tending to infinite, it can be considered a particular case of implied weighting (in which the information from character congruence is completely ignored during searches) (Mirande, 2009). Implied weighting was also defended in terms of stability of the analyses to the addition of new information (Goloboff et al., 2008b).

In characters with many missing entries the test of the phylogenetic analysis for the hypotheses of homology defined in each character state is weaker relative to characters with fewer missing data. This usually produce characters with many missing data to have artificially lower number of steps - and hence higher weights - when optimized on most parsimonious trees. The extended implied weighting method, recently implemented in TNT under the command "xpiwe" was used as a solution of that potential problem (Goloboff, 2013). This method prevents the characters with many missing entries to have artificially high weights. This is done for each character by assuming extra steps among the missing entries that are proportional to the homoplasy of the observed distribution of states. This calculation is mathematically equivalent to using different values of $\mathrm{K}$ for each character depending on its proportion of missing entries. Characters with many missing data are assigned by this method with lower values of $\mathrm{K}$ and consequently the homoplasy is more strongly down-weighted relative to characters with fewer missing entries (for details read Goloboff, 2013). Stability was used as a meta-criterion to choose some values of $\mathrm{K}$ to produce the final hypothesis. As in Mirande $(2009,2010)$ and Mirande et al. (2011) the measures of stability used were the distortion coefficient ("tcomp") (Farris, 1989) and the SPR distance ("sprdiff") (Goloboff, 2008). Clade support was evaluated through Symmetric Resampling, showing values of groups supported/contradicted (GC) (Goloboff et al., 2003) obtained from 200 replicated matrices. Each resampled matrix was analyzed using Sectorial Searches and Tree-Drifting (Goloboff, 1999). Stability of clades is expressed as GC values using as source the consensus of the most parsimonious trees at each value of $\mathrm{K}$, as in Mirande $(2009,2010)$. All searches were made through a TNT script, which is provided in Supplementary File 1.

Specimens were cleared and stained (C\&S) following Taylor \& van Dyke (1985). Examined specimens, additional to those cited by Mirande (2010) and Mirande et al. (2011), are listed in Comparative Material. Museum acronyms are as follows: CI-FML (Fundación Miguel Lillo, San Miguel de Tucumán), CZUT-IC (Ictiología, Colección Zoológica, Universidad del Tolima, Ibagué, Colombia), MCP (Museu de Ciências e Tecnologia, Pontifícia Universidade Católica de Rio Grande do Sul, Porto Alegre), MHNG (Musée d'histoire naturelle, Genève), and USNM (National Museum of Natural History, Smithsonian Institution, Washington).

\section{Results}

Character Descriptions. Twenty-six characters are herein added to the list of 366 characters presented by Mirande (2010) and Mirande et al. (2011). Character 123 from Mirande $(2009,2010)$ is similar to characters 368 and 369 in this study. Therefore that character and those herein added are described in some detail starting from the number 367 . The complete list of characters is 
provided in the Supplementary File 2. Most of the characters added were coded following the definitions of Vari \& Harold (2001). References to their numbers in the phylogeny of Vari \& Harold (2001) are given after the string "VH" in the corresponding character definitions. The data matrix is presented in the Supplementary File 3, but the coding of the examined species relevant for the phylogeny of Carlastyanax is also discussed.

123. Number of rows of premaxillary teeth: ( 0 ) one or two; (1) three.

The anterior row of premaxillary teeth is usually composed of aligned teeth or it has one or two teeth whose bases are slightly more anterior than the remaining ones (state 0 ). In some species the anterior teeth at the premaxilla, which have intraosseous development, are not aligned and form two recognizable rows at least in some portion of the bone (state 1). In this state even the developing teeth that are lodged inside the premaxilla are not aligned, and the alveolar portion of the premaxilla is consequently expanded longitudinally (i.e., anteroposteriorly) relative to the species with only one row of intraosseous premaxillary teeth. This character is similar to characters 368 and 369 (see below).

367. Form of third dentary tooth: (0) similar to remaining teeth of dentary; (1) strongly decurved posteriorly.

In most species of the Characidae, the third dentary tooth is rather similar to the remaining teeth (state 0 ). The hooked form of the third dentary tooth was used by Géry (1972) to justify the creation of Carlastyanax, including $A$. aurocaudatus as its single species. In this state the third dentary tooth is strongly decurved posteriorly relative to the remaining teeth from the dentary (state 1; Fig. 2). This character was observed only in Carlastyanax aurocaudatus, and it constitutes an autapomorphy of this terminal.

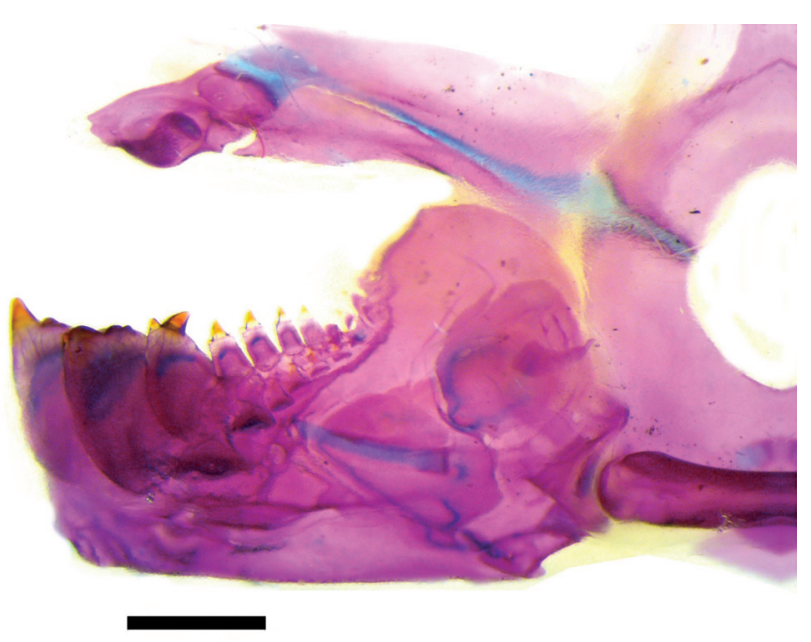

Fig. 2. Lower jaw and part of the suspensorium of Carlastyanax aurocaudatus, CI-FML 5015, $44.4 \mathrm{~mm} \mathrm{SL}$, lateral view, anterior to left. Scale bar $=1 \mathrm{~mm}$.
368. Premaxillary dentition: (0) one or more series of similar teeth; (1) a recognizable triad of larger teeth with rounded base.

In most characids there is one or two series of premaxillary teeth, which are rather homogeneous in form and size or gradually decrease in size laterally (state 0 ). Vari \& Harold (2001) recognized a different dentition in most species of Creagrutus and Piabina Reinhardt, genera whose species have a medial triad of larger teeth with rounded base. This triad is usually margined anteriorly by teeth from a primary premaxillary row of teeth, according to Vari \& Harold (2001) (state 1; Vari \& Harold, 2001: figs. 1-2; Fig. 3). The homology of the teeth of the triad and the primary row is not clear, but the posterior teeth from the triad seem to be homologous, by development and position, to the medial two teeth of the species having one or two regular rows of premaxillary teeth. This character could be considered as part of a single series of transformation with the character 123 , given that all the species having a triad, as described by Vari \& Harold (2001) also have three recognizable rows of premaxillary teeth, but not all the species with three rows of premaxillary teeth have a recognizable triad. The latter condition was observed by Vari \& Harold (2001) and herein confirmed in Creagrutus gephyrus, along with the examined species of Brycon Müller \& Troschel, Chalceus Cuvier, and Triportheus Cope. In some of these species there is a tooth situated just anterior to the two medial teeth from the posterior premaxillary row, but this tooth is more slender and similar to the remaining teeth with intraosseous development. The state 1 was coded for Carlastyanax, Piabina, and all the examined species of Creagrutus except $C$. cracentis and $C$. gephyrus, which were coded as state 0 .

\section{Gap between two medial teeth from anterior premaxillary} row: (0) distinctly greater than the gap between remaining teeth; (1) equal to gap between remaining teeth (VH2).

As described by Vari \& Harold (2001), in several species of Creagrutus there is a gap between the first and second teeth of the primary premaxillary row that in some species is filled by the anterior tooth of the triad (state 0; Vari \& Harold, 2001: figs.

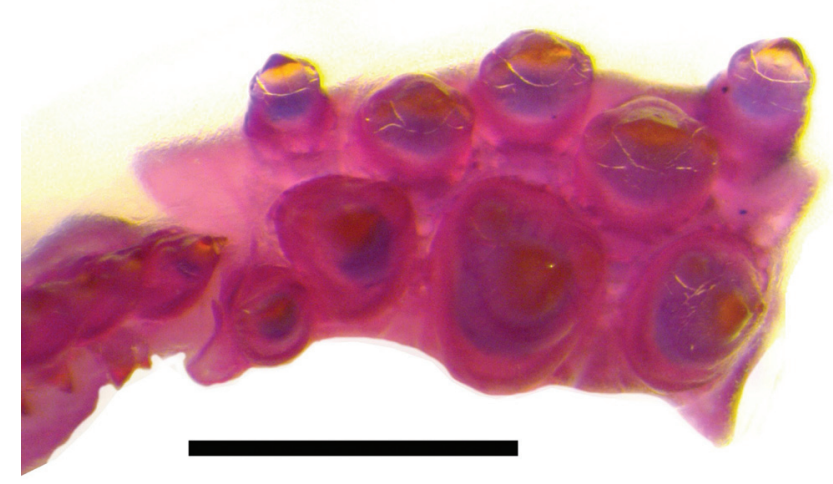

Fig. 3. Premaxilla of Carlastyanax aurocaudatus, CI-FML 5015, $44.4 \mathrm{~mm} \mathrm{SL}$, ventral view, medial to right. Scale bar $=1 \mathrm{~mm}$. 
1 and 3; Fig. 3). This condition is absent in other species of the genus (state 1; Vari \& Harold, 2001: fig. 2). State 0 could be interpreted as two rows of premaxillary teeth, with the anterior one in zigzag. This character is only coded for the species with a recognizable triad of premaxillary teeth. Among the examined species, only Creagrutus anary Fowler, C. atrisignum, $C$. meridionalis, and C. taphorni Vari \& Harold have state 1.

370. Position of lateralmost tooth of outer premaxillary row: (0) anteriorly displaced relative to remaining teeth; (1) aligned with remaining teeth of row (VH4).

According to the description presented by Vari \& Harold (2001), in Creagutus there is a primary row of premaxillary teeth and a single lateral tooth that is usually situated anterolaterally to the primary row (state 0; Vari \& Harold, 2001: figs. 1-3). Medial teeth of the primary premaxillary row of Creagrutus have intraosseous development, while in the lateral ones the development is extraosseous. Thus, the primary row, according to the definition by Vari \& Harold (2001) has a double origin. The anterolateral tooth of Creagrutus, treated in this character, has intraosseous development and is considered herein as homologous to some tooth of the anterior premaxillary row of other characids. The species in which all the teeth of the anterior premaxillary row are aligned are coded with the state 1 . The state 0 is coded, among examined species, in Bryconamericus exodon, $B$. emperador, Piabina argentea Reinhardt, and all the species of Creagrutus except $C$. cracentis. Vari \& Harold (2001) coded the state 1 also in C. maxillaris (Myers).

371. Anterior process of maxilla: (0) more slender than its posterior region; (1) as expanded as its posterior region (VH5).

Usually among characids, the anterior process of the maxilla is much more slender than the laminar region of the bone, which is variably expanded (state 0). Vari \& Harold (2001) described a thickened and robust posterior region of the maxilla in all species of Creagrutus except $C$. cracentis and C. maxillaris (state 1; Vari \& Harold, 2001: fig. 5B). In the phylogeny of Vari \& Harold (2001) this character was proposed as a synapomorphy of Creagrutus, with a reversion in a clade composed of these two species. This character is herein coded as polymorphic in Micralestes stormsi Boulenger, which also has a somewhat thickened anterior region of the maxilla, although not to the same degree as in species of Creagrutus.

\section{Flexion on maxilla posterior to site of attachment with} premaxilla: (0) absent or not pronounced, maxilla rather straight; (1) flexion pronounced (VH6).

As noted by Vari \& Harold (2001), the ascending process of the maxilla is rather aligned with its lamellar region in most characids (state 0 ). They noted a different state in species of Creagrutus, in which the maxilla has a distinct flexion just posterior to the site of attachment of the ligament connecting this bone with the distal tip of the premaxillary alveolar arm. This flexion gives to the maxilla an angled or curved aspect in lateral view (state 1; Figs. 4-5). Discrete states are difficult to

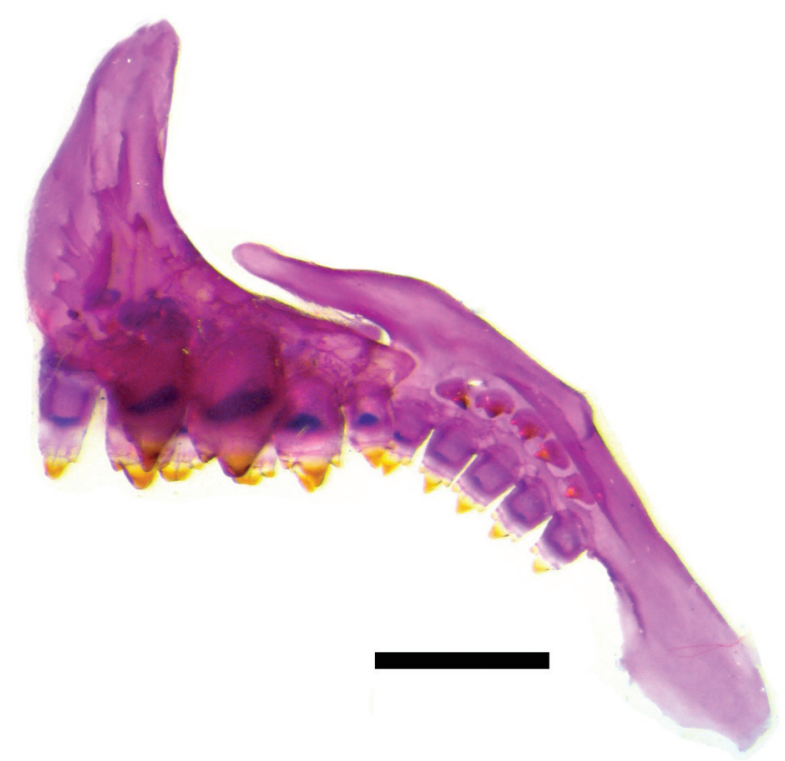

Fig. 4. Premaxilla and maxilla of Carlastyanax aurocaudatus, CI-FML 5015, $44.4 \mathrm{~mm}$ SL, medial view, anterior to left. Scale bar $=1 \mathrm{~mm}$.

define for this character and the species having morphologically intermediate states were coded as polymorphic. The state 1 of this character refers only to a flexion on the sagittal plane of the maxilla, excluding cases in

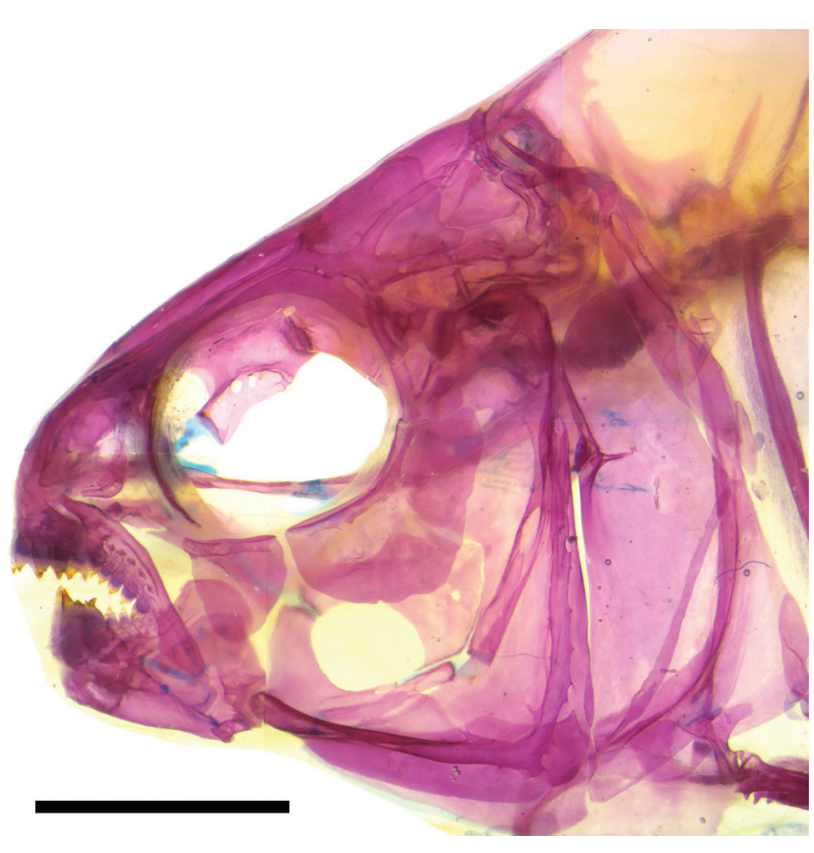

Fig. 5. Cranium and pectoral girdle of Carlastyanax aurocaudatus, CI-FML 5015, $44.4 \mathrm{~mm} \mathrm{SL}$, lateral view, anterior to left. Gill skeleton and right suspensorium removed. Scale bar $=5 \mathrm{~mm}$. 
which the ascending process of the maxilla is curved medially, which are coded with state 0 . State 1 is herein coded only for Carlastyanax and the examined species of Creagrutus.

373. Form and insertion of primordial ligament: ( 0 ) flat and inserted on ascending process of maxilla; (1) round in cross section and inserted on distal half of maxillary lamella (VH8).

The primordial ligament usually originates at the lateral surface of the anguloarticular and the primordial membrane. In most characids, this ligament is flat and inserts on the proximal portion of the ascending maxillary process (state 0 ). As noted by Vari \& Harold (2001), the primordial ligament is stronger, round in cross section, and inserts on middle length of the maxillary laminar portion in the species of Creagrutus (state 1). This state was also herein observed in Carlastyanax.

374. Form and insertion of primordial ligament: (0) inserted on middle length of maxillary lamella or dorsal to it; (1) inserted near distal tip of maxilla. (VH9).

In some species of Creagrutus, as observed by Vari \& Harold (2001), the primordial ligament is particularly strong and inserts on the region near the distal tip of the maxilla (state 1). This character and the preceding one form a series of nested homologies (sensu Nixon \& Carpenter, 2012), and the two characters might alternatively be interpreted as a single additive character with three states. The binary coding of this additive series of transformation follows Mirande (2010), which used this method to facilitate further modifications in the list of characters, considering the great diversity of still non-analyzed species of characids and the intended "modular" nature of that matrix. State 1 was not observed among species examined, and only Creagrutus amoenus Fowler and C. kunturus Vari, Harold \& Ortega are coded with that state following observations by Vari \& Harold (2001). Thus, this character is informative only in the analyses based on the Extended Matrix.

375. Origin of primordial ligament: $(0)$ on anguloarticular; (1) on anguloarticular and quadrate (VH9).

The primordial ligament originates on the primordial membrane and the anguloarticular in most characids (state 0 ). Vari \& Harold (2001) noted that in most species of Creagrutus the posterior region of the primordial ligament bifurcates posteriorly, attaching to the anguloarticular and also laterally to the quadrate (state 1; Vari \& Harold, 2001: fig. 7). In most alestids, as described and illustrated by Zanata \& Vari (2005: fig. 21), the primordial ligament is also split ventrally and its ventral division attaches to the quadrate. We examined the alestid Micralestes stormsi, and in this species the primordial ligament attaches only to the anguloarticular. Therefore, this character is coded as 0 in that species and as uncertain in the remaining alestids. Among examined species, state 1 is coded in Creagrutus anary, C. atrisignum, C. cracentis, C. gephyrus, $C$. meridionalis, and C. taphorni.
376. Ligament between premaxilla and maxilla: (0) weak, attached to a moderately bifurcated premaxilla; (1) strong, attached to a greatly bifurcated premaxilla (VH10).

In the examined characids, there is a ligament between the posterior tip of the alveolar arm of the premaxilla and the proximal region of the ascending process of the maxilla. In most species, that ligament is rather weak and the region of the premaxilla where it originates is moderately notched (state 0). However, as noted by Vari \& Harold (2001), this ligament is comparatively strong and round in cross section in Creagrutus and Piabina. Also, the area of origin of this ligament is expanded in species of those genera, with the distal bifurcation of the premaxilla comparatively more pronounced (state 1). The state 1 is also present in Carlastyanax.

\section{Ligament between premaxilla and distal tip of ascending} maxillary process: (0) absent; (1) present. (VH11).

In most characids, the distal tip of the ascending maxillary process is attached through ligaments only to the lateral wing of the mesethmoid and the posteroventral tip of the premaxilla (state 0). As noted by Vari \& Harold (2001: fig. 8B), in Creagrutus there are two additional ligaments that originate at the dorsal margin of the alveolar premaxillary region and insert on the ascending maxillary process. One of those ligaments inserts on the tip of the ascending maxillary process (state 1) and the other inserts on its middle portion (see comments on next character). The ligament that inserts on the anterodosal tip of the maxilla was herein observed only in species of Creagrutus.

\section{Ligament between premaxilla and middle portion of} ascending maxillary process: (0) absent; (1) present (VH12).

As described in the preceding character, the ascending maxillary process is not connected through ligaments to the alveolar arm of the premaxilla in most characids (state 0 ), while in the species of Creagrutus there are two ligaments from the premaxilla that inserts on the ascending maxillary process. One of these ligaments inserts on the middle portion of the ascending maxillary process (state 1; Vari \& Harold, 2001: fig. 8B; Fig. 6). This ligament is present in Carlastyanax aurocaudatus and the examined species of Creagrutus.

379. Number of teeth on anterior row of dentary: ( 0 ) eight or fewer; (1) ten or more (VH17).

The total number of teeth on the anterior row of the dentary is highly variable within the Characidae, but it is usually higher than 10 (state 1). Vari \& Harold (2001) noted that in many species of Creagrutus this number is smaller and there are usually fewer than nine dentary teeth (state 0 ). State 0 was coded among the Stevardiinae in Bryconadenos tanaothoros, Microgenys minuta, Piabina argentea, and all examined species of Creagrutus except $C$. cracentis and $C$. gephyrus. Vari \& Harold (2001) also observed state 1 in Creagrutus maxillaris. 


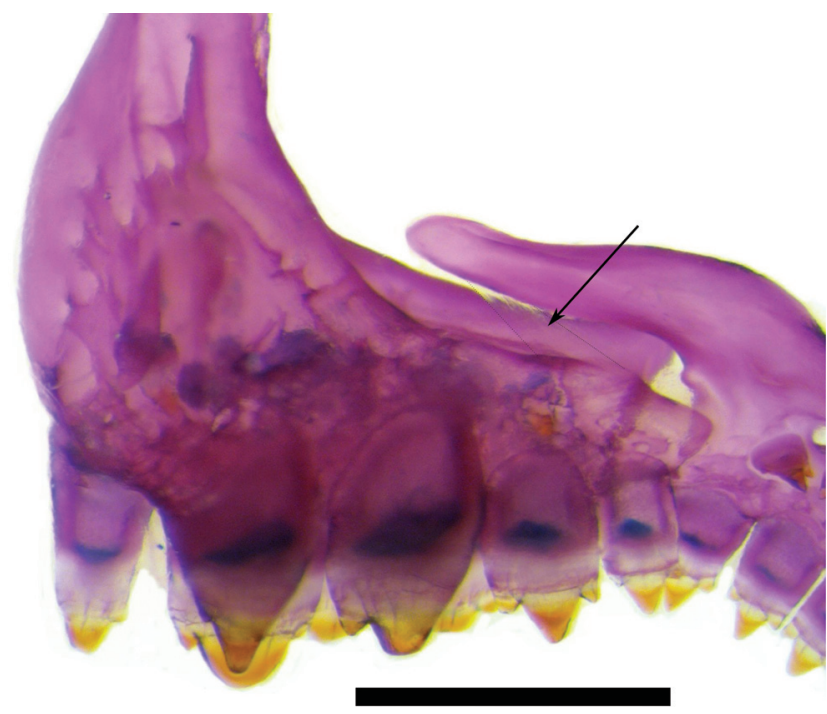

Fig. 6. Premaxilla and part of the maxilla of Carlastyanax aurocaudatus, CI-FML 5015, $44.4 \mathrm{~mm} \mathrm{SL}$, medial view, anterior to left. Scale bar $=1 \mathrm{~mm}$. Arrow indicates the ligament between middle length of ascendant maxillary process and the premaxilla, described in the character 378 .

380. Number of cusps of anterior dentary teeth: (0) three or fewer; (1) five or more (VH18).

The number of cusps of dentary teeth is highly variable among the Characidae, but in most species five or more cusps are present (state 1). As noted by Vari \& Harold (2001), the dentary teeth of most species of Creagrutus have only three cusps (state 0 ). In the Stevardiinae, state 0 was also observed in Microgenys minuta and Knodus pectinatus. Conical teeth were interpreted as having a single cusp, and species with that condition were consequently coded with state 0 .

381. Expansion of dentary lateral to anguloarticular: (0) closer to Meckelian cartilage than to articular socket; (1) closer to articular socket than to Meckelian cartilage (VH19).

In most characiforms, the anguloarticular has two processes that are directed anteriorly and anterodorsally. Those processes articulate with the posterior portion of the dentary. The dentary, although firmly overlapping laterally the horizontal process of the anguloarticular, is typically distant from the anguloarticular socket that articulates with the quadrate. In that condition, the posterior margin of the dentary surpasses only slightly the posterior margin of the Meckelian cartilage (state 0; Figs. 3 and 5). In Creagrutus, on the other hand, the dentary broadly overlaps the anguloarticular, and its posterior margin almost reaches the anguloarticular socket (state 1; Vari \& Harold, 2001: fig. 9). This character and the 108 of Mirande (2010) describe a series of nested homologies (sensu Nixon \& Carpenter, 2012) and both characters represent the binary coding of a single additive transformation series of three states. State 1 was observed only in Creagrutus, examined species of Serrasalmidae, and African species of the Alestidae.

382. Posterodorsal region of anguloarticular: $(0)$ vertical; (1) anterodorsally angled (VH20).

In most characids, there is an anterodorsal process in the anguloarticular overlapping laterally the posterodorsal margin of the dentary. As noted by Vari \& Harold (2001), this process is almost vertical (state 0) in most species of Creagrutus, rather than anterodorsally angled (state 1) as in the usual condition of the Characidae. State 0 was also observed in Carlastyanax aurocaudatus (Figs. 3 and 5), Knodus pectinatus, and all the examined species of Creagrutus, except C. cracentis and C. gephyrus.

383. Posterior region of mesopterygoid: $(0)$ overlapping metapterygoid; (1) separate from metapterygoid (VH22).

The posterior portion of the mesopterygoid typically articulates with the anterior margin of the metapterygoid and the dorsal region of the quadrate (state 0 ), whereas in many species of Creagrutus the mesopterygoid is considerably less developed, not reaching to the metapterygoid or the quadrate (state 1; Vari \& Harold, 2001: fig. 10B). State 1 was observed only in Carlastyanax aurocaudatus, Knodus pectinatus, and the examined species of Creagrutus, except C. gephyrus.

384. Medial dorsal ridge of quadrate: (0) absent; (1) present, laterally covering the symplectic (VH25).

The quadrate typically has a notch, most evident in lateral view, in which the symplectic inserts (state 0 ). Vari \& Harold (2001: fig. 11) described the presence of a dorsally oriented ridge on the quadrate that laterally covers the symplectic (state 1). State 1 was hypothesized as a synapomorphy of Creagrutus by Vari \& Harold (2001), with a single reversion in C. lepidus Vari, Harold, Lasso \& Machado-Allison.

385. Form of fourth infraorbital: ( 0 ) quadrangular, reaching posterior margin of third and fifth infraorbitals; (1) triangular, excluded from posterior margin of infraorbital series (VH31).

The fourth infraorbital is usually quadrangular among examined characids, with its posterior margin as deep as the anterior one (state 0). Vari \& Harold (2001) noted that in Piabina argentea the fourth infraorbital is approximately triangular, with its posterior margin angled and not reaching the posterior margin of the third and fifth infraorbitals, consequently being excluded from the posterior margin of the infraorbital series (state 1; Vari \& Harold, 2001: fig. 12B). State 1 was also observed in Aphyocharax anisitsi Eigenmann \& Kennedy, $A$. dentatus Eigenmann \& Kennedy, and Hasemania nana (Lütken). This character is coded as inapplicable in Carlastyanax aurocaudatus and the other species lacking the fourth infraorbital (Fig. 5).

386. Parietal branch of supraorbital laterosensory canal: (0) extended posteriorly to middle region of parietal; (1) absent or reaching only to anterior half of parietal (VH39). 
In most characids, the parietal branch of the supraorbital laterosensory canal (sensu Di Dario, 2004) runs longitudinally by the posterodorsal region of the frontal and reaches to the posterior margin of the parietal (state 0 ). This branch is absent or reduced in some species, not reaching the parietal or reaching only the anterior half of this bone (state 1). This character is variable in Bryconadenos tanaothoros, Bryconamericus mennii Miquelarena, Protogino, Filiberto \& López, B. rubropictus (Berg), and Cyanocharax obi, which were coded as polymorphic. Carlastyanax aurocaudatus, Creagrutus maracaiboensis, and several non-stevardiin species have state 1 (Fig. 5).

387. Cartilage-filled region anterior to scapular foramen: (0) present, wider than anterior process of scapula; (1) reduced by expansions of coracoid and cleithrum (VH49).

In most characids, the region anterior to the scapular foramen is cartilaginous. That cartilage is limited dorsally by the cleithrum, ventrally by the coracoid, and posteriorly by an anterior projection of the mesocoracoid (state 0 ). Vari \& Harold (2001) noted that in species of Creagrutus examined by them that region is almost completely ossified, with the consequence that this cartilage is small (state 1). That condition was also observed in several other characids, including all the examined species of Creagrutus, but not in Carlastyanax, in which this cartilage is well developed.

388. Number of scales in lateral series: (0) 33 or more; (1) 32 or fewer (VH51).

The number of scales in the lateral series is frequently used to distinguish between species of several genera of the Characidae. The number of scales is usually higher than 35 in the family (state 0 ), with several evidently parallel increases of this number in various clades. Vari \& Harold (2001) noted that within Creagrutus there is a reduced number of scales in the lateral series of the trans-Andean species $C$. maracaiboensis and C. nigrostigmatus Dahl, which have less than 33 scales (state 1). This reduced number of scales in the lateral series was also observed herein in Aphyocharax nattereri (Steindachner), Hyphessobrycon elachys Weitzman, Moenkhausia sanctaefilomenae (Steindachner), Pristella maxillaris (Ulrey), Thayeria boehlkei Weitzman, and $T$. obliqua Eigenmann. A relatively low number of lateral scales in Creagrutus maracaiboensis and C. nigrostigmatus is unique among the analyzed Stevardiinae.

389. Number of post-anal scales: $(0)$ one or two median scales; (1) four or five median scales (VH52).

Most characids have one or two median scales between the anus and the anal fin (state 0). Vari \& Harold (2001) noted that Creagrutus cracentis, C. maxillaris, and C. ungulus Vari $\&$ Harold have four or five scales in that region (state 1).

390. Midlateral body pigmentation: (0) not pigmented or with a continuous lateral stripe; (1) with a series of dark spots that coalesce during development (VH54).
Most characids lack a broad lateral stripe, or if present, it is regular and homogeneously intense along the lateral of the body (state 0 ). That stripe is usually silver in live specimens and it turns either diffuse or dark in fixed material, depending on the species and conditions of fixation. State 0 might actually not represent a single condition, but more studies about the histological nature of this pigmentation and the influence of time and process of fixation would be necessary in order to convincingly divide it into more states. Regardless of that question, Vari \& Harold (2001) noted that juvenile specimens of Creagrutus amoenus and C. kunturus have dark spots on body sides that coalesce during development, forming a lateral stripe in adults (state 1). This pattern of development of the lateral stripe was not observed in other species of the Characidae. This character is not variable and therefore it is uninformative for parsimony analyses in the Examined Matrix, but it is informative in the Extended Matrix.

391. Total number of vertebrae: (0) 33 or fewer; (1) 34 or more (VH56).

The number of vertebrae is highly variable within the Characidae, but there are usually between 35 and 40 vertebrae (state 1). Vari \& Harold (2001) noted that in C. maracaiboensis and $C$. nigrostigmatus, which are trans-Andean species of the genus, a lower number of vertebrae (less than 34) is present (state 0 ). This condition was also observed in several other species of the family, but interestingly not in the examined members of the Stevardiinae.

392. Notochondral mineralizations: (0) absent; (1) present (VH57).

The notochord persists in the region posterior to the uroneurals, between the base of the first and second caudalfin rays, and it is margined by the opisthural cartilage (McDowall, 1999). The notochord is not stained with alizarin in most species, evidencing a lack of mineralization on it (state $0)$. Vari \& Harold (2001) described a condition in which the notochord is mineralized, staining deep red with alizarin (state 1). This state is present in Creagrutus atratus Vari \& Harold, C. bolivari Schultz, and C. magoi Vari \& Harold by Vari \& Harold (2001) and it was not observed herein in other species. In consequence, this character is not variable for the Examined Matrix, but it is informative in the Extended Matrix.

Phylogenetic results. Almost identical phylogenetic results of the Examined Matrix were obtained in a rather wide range of values of $\mathrm{K}$. This range extends from the $7^{\text {th }}$ to the $10^{\text {th }}$ value of $\mathrm{K}$ (9.37 to 12.31 ), with two slightly different configurations of 2581 steps each. The first of these trees (obtained in values of $\mathrm{K}$ from 9.37 to 11.21) is the most stable according to the measures of sprdiff and tcomp (see Material and Methods). As the differences of the two trees are minimal, both in terms of topology and in measures of stability, the strict consensus of the most parsimonious trees obtained under all these four values of $\mathrm{K}$ is proposed as our final hypothesis (Fig. 7). 
The relationships obtained after the analysis of the Extended Matrix are comparatively less stable, but much of their instability is found to be within Creagrutus. Most of the analyzed characters are currently unknown for many species of Creagrutus examined by Vari \& Harold (2001) and were coded as question marks in the Extended Matrix. This situation produces a high number of most parsimonious trees and a comparatively lower resolution due to the presence of many zero length branches that collapse in the consensus. The low resolution in terms of relationships within Creagrutus, in turn, affected the calculations of tcomp. However, the sprdiff measures show rather stable results in the $9^{\text {th }}$ to $11^{\text {th }}$ values of $\mathrm{K}$ (11.47 to 13.88). The topology of the most parsimonious trees obtained with the Extended Matrix is almost identical to the ones obtained after the analysis of the Examined Matrix, apart from the inclusion of additional terminals in the latter (Fig. 8).

The extended analysis was performed mainly to evaluate, with all the available previously published evidence, if Carlastyanax is the sister group of Creagrutus, or if it might be included in that genus. The internal relationships of Creagrutus are very complex, as noted by Vari \& Harold (2001), and its resolution is beyond the scope of this paper. However, according to the results of our analyses, Carlastyanax is the sister group of Creagrutus in a clade of the Stevardiinae that also includes Bryconamericus exodon, Microgenys Eigenmann, and Piabina (Fig. 7). The synapomorphies of the most inclusive clades of Stevardiinae and the autapomorphies of Carlastyanax aurocaudatus are listed below, along with a more in depth discussion focused on the clades which are more closely related to Carlastyanax. Convergences and reversions are listed only within the Stevardiinae. In the following section, clades are discussed following the nodes in the cladogram depicted in Fig. 7. The number of the characters supporting the monophyly of each node is given in parentheses after its definition, according to the list of characters provided in Supplementary File 2. Values in parentheses after each node indicate (stability/support) indexes, which are expressed as GC values and explained in the Material and Methods section. The GC values are negative in some clades, meaning that there is an alternative clade having a higher frequency in the source trees. This is comparatively more frequent in values of support than in those of stability and are denoted with a "<" before the corresponding number. Support was calculated with $K=10.24$, corresponding to the $8^{\text {th }}$ value of $\mathrm{K}$ herein explored.

Node 238: Stevardiinae (stability: 81/support: 53).

The composition and synapomorphies of the Stevardiinae are the same as those proposed by Mirande (2010), but our results indicate that the genus Carlastyanax should be revalidated. This clade is similar to "clade A" of Malabarba \& Weitzman (2003), and is also similar to a clade based on molecular data proposed by Javonillo et al. (2010), which was also named "clade A" in that study. The Stevardiinae, according to the molecular phylogeny presented by Oliveira et al. (2011) includes Bryconamericus emperador and Markiana nigripinnis as the sister group of a monophyletic unit compatible with our Stevardiinae. Although the latter species are not closely related with the Stevardiinae in the analyses presented herein, the congruence in the monophyly of the Stevardiinae among hypotheses generated from morphological and molecular analyses is remarkable given the general low stability and support of most of the internal clades of the Characidae when different kinds of data are analyzed. The close relationship of Markiana with the Stevardiinae was also hypothesized by Baicere-Silva et al. (2011) based on spermatic evidence. This hypothesis is not compatible with our results, in which this genus is related with Astyanax, but the congruence between molecular and spermatic data in this issue is remarkable. Markiana is a morphologically divergent genus that was found to have an unstable position across different analyses by Mirande (2010), and its inclusion in the Stevardiinae should be better evaluated in phylogenetic analyses combining different sources of information.

\section{List of synapomorphies:}

1. Epiphyseal branch of supraorbital canal (84): $(0>1)$ absent. Reversed in Argopleura magdalenensis and in the node 352, composed of Carlastyanax, Creagrutus, Microgenys, and Piabina.

\section{Number of branched rays on dorsal fin (270): $(1>0)$ eight} or fewer.

3. Number of dorsal-fin pterygiophores (276): $(1>0)$ nine or fewer. Reversed in Mimagoniates rheocharis Menezes \& Weitzman.

Node 237: Stevardiinae except Hemibrycon Günther (81/41).

The position of Hemibrycon at the base of the Stevardiinae was proposed by Mirande (2010). The internal relationships of this clade are different from those proposed in the literature. Two of three synapomorphies previously proposed to this clade were corroborated as such according to our results. In the phylogeny proposed by Oliveira et al. (2011), Hemibrycon taeniurus (Gill), the single species of the genus included in their analyses, is part of a less inclusive clade within the Stevardiinae. This incongruence could be, at least partially, related to the fact that different species of Hemibrycon were analyzed in both studies.

\section{List of synapomorphies:}

1. Small foramen near posterior margin of pterosphenoid (44): $(0>1)$ present, pierced by a branch of supraorbital nerve. Reversed in Mimagoniates rheocharis.

2. Contact between ectopterygoid and anterodorsal region of quadrate (162): $(0>1)$ absent. Reversed in Pseudocorynopoma doriae Perugia.

Node 236: Stevardiinae except Bryconamericus mennii and Hemibrycon $(81 / 28)$ 


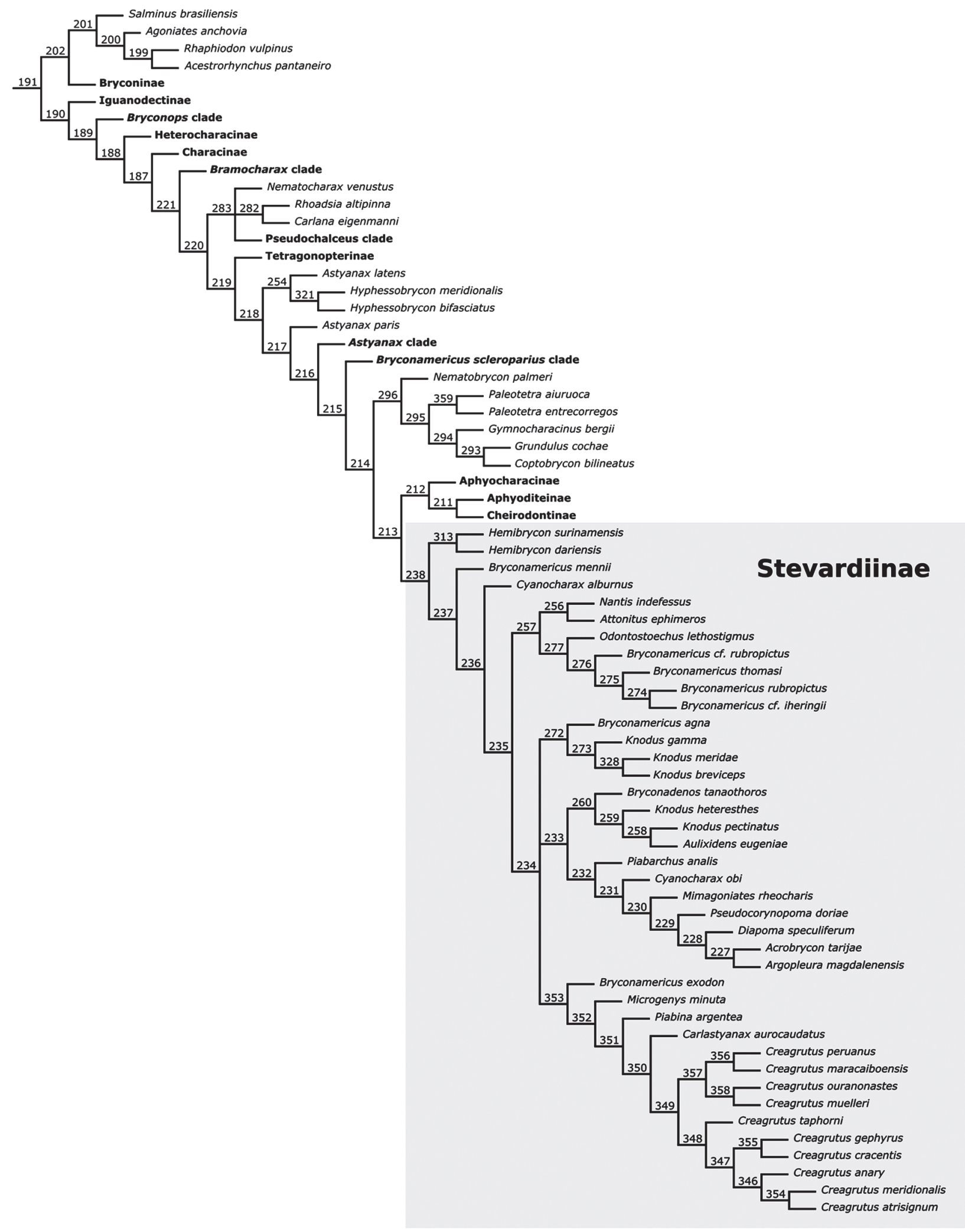

Fig. 7. Cladogram showing relationships of the Characidae obtained with the Examined Matrix. Node numbers correspond to those cited on the text. 
In the phylogeny proposed by Mirande (2010), Bryconamericus mennii is included in a clade with Acrobrycon Eigenmann \& Pearson, Attonitus Vari \& Ortega, Aulixidens, Diapoma Cope, Mimagoniates Regan, and Pseudocorynopoma Perugia. In our analyses, B. mennii is the sister group of this large clade of stevardiins. Although the character 359 (form of the sperm nuclei) is optimized as a synapomorphy of this clade, it should be noted that this character is unknown and hence coded as missing in many of the species within this clade. Thus, both the relationships herein proposed for this clade and the synapomorphic condition for that character in this node should be considered as provisional.

\section{List of synapomorphies:}

1. Rows of gill rakers on second ceratobranchial (193): ( $0>$ 1) two. Reversed in nodes 230, composed of Acrobrycon, Argopleura Eigenmann, Diapoma, Mimagoniates, and Pseudocorynopoma and 351, composed of Carlastyanax, Creagrutus, and Piabina.

2. Sperm nuclei (359): $(0>1)$ elongated, with longitudinal axis longer than 2 micrometers.

Node 235: Stevardiinae except Bryconamericus mennii, Cyanocharax alburnus (Hensel), and Hemibrycon $(36 /<1)$.

The relatively basal position of Cyanocharax alburnus in the Stevardiinae was not explicitly proposed in previous studies. Cyanocharax alburnus lacks most features that were considered by Malabarba \& Weitzman (2003) as presumably apomorphic for the genus, with the exception of the presence of only six branched pelvic-fin rays. Cyanocharax Malabarba \& Weitzman is polyphyletic according to our results, with $C$. obi as the sister group of a clade composed of Acrobrycon, Argopleura, Diapoma, Mimagoniates, and Pseudocorynopoma. However, those relationships have a low support, and that is also the case of most basal clades of the Stevardiinae. In the phylogeny proposed by Oliveira et al. (2011), which was based on molecular data, Cyanocharax alburnus is deeply nested within the Stevardiinae, as the sister group of a clade composed of Bryconamericus exodon, Hypobrycon maromba Malabarba \& Malabarba, and Odontostoechus lethostigmus Gomes. The phylogeny proposed by Javonillo et al. (2010) included four species of Cyanocharax. In the hypotheses presented by those authors, Cyanocharax is paraphyletic, since it includes Diapoma. A phylogenetic hypothesis for Cyanocharax was published in the description of Cyanocharax obi (Casciotta et al., 2012). In that analysis, the outgroup was composed of unspecified species of Bryconamericus Eigenmann, Diapoma, Knodus Eigenmann, and Odontostoechus Gomes. Casciotta et al. (2012) conducted two different analyses: a morphological one, in which no species of other genera were included to test the monophyly of Cyanocharax, and a Bayesian analysis including only molecular data. In their molecular phylogeny, Casciotta et al. (2012) also obtained Cyanocharax as paraphyletic in terms of Diapoma.

\section{Synapomorphy:}

1. Bony hooks at base of pelvic-fin rays of adult males (313): $(0>1)$ as numerous as on segmented portion of rays. Reversed in Argopleura magdalenensis, Bryconamericus agna, Creagrutus atrisignum, C. cracentis, and Piabarchus analis.

Node 257: Attonitus, Nantis, Odontostoechus, and some Bryconamericus $(4 /<1)$.

Most species included in this clade were hypothesized as related to Creagrutus and Piabina by Mirande (2010). In the present hypothesis this clade also includes Attonitus, which was proposed as related to Aulixidens by Mirande (2010), and excludes Creagrutus and Piabina. This clade does not include $B$. exodon, the type species of the genus. Consequently, the species of Bryconamericus included in this clade should be assigned either to Odontostoechus or to a new genus, but more thorough studies including a higher number of species possibly related to this clade are needed.

\section{List of synapomorphies:}

1. Position of opening on neurocranium communicating with laterosensory canal of sixth infraorbital (77): $(0>1)$ in frontal. Convergent in Knodus pectinatus, Piabarchus analis, and in node 352, composed of Carlastyanax, Creagrutus, Microgenys, and Piabina.

2. Length of ascending process of premaxilla (104): $(0>1)$ reaching just anterior end of nasal. Convergent in Bryconamericus agna and Microgenys minuta.

3. Number of branched anal-fin rays (287): $(1>0) 17$ or fewer. Convergent in Knodus pectinatus.

4. Bony hooks on last pelvic-fin ray of adult males (314): (0> 1) as numerous as in other rays. Convergent in Creagrutus gephyrus, C. taphorni, Knodus meridae, and in node 231, including Acrobrycon, Argopleura, Diapoma, Mimagoniates, Pseudocorynopoma, and Cyanocharax obi.

Node 234: Acrobrycon, Aulixidens, Argopleura, Bryconadenos, Carlastyanax, Creagrutus, Diapoma, Knodus, Microgenys, Mimagoniates, Piabarchus Myers, Piabina, Pseudocorynopoma, some species of Bryconamericus, and some species of Cyanocharax Malabarba \& Weitzman $(4 /<1)$.

The monophyly of this clade was not previously proposed. A close relationship between Knodus and Aulixidens and the exclusion of Creagrutus and Piabina from the clade including some species of Bryconamericus, Nantis, and Odontostoechus are the main differences in relation to the phylogeny proposed by Mirande (2010). According to Javonillo et al. (2011), Diapoma is related to Cyanocharax, and is not related to the remaining genera bearing a caudal-fin gland (in this analysis: Acrobrycon, Argopleura, Mimagoniates, and Pseudocorynopoma). This hypothesis is corroborated herein. 


\section{List of synapomorphies:}

1. Horizontal process of anguloarticular (108): $(0>1)$ broadly covered by dentary to tip of Meckelian cartilage. Reversed in Aulixidens eugeniae.

2. Number of maxillary teeth (136): $(1>0)$ up to three.

Node 272: Bryconamericus agna and Knodus $(18 /<1)$.

A close relationship between Bryconamericus agna and the group of species of Knodus in this clade, which includes the type species of Knodus (K. meridae), is proposed for the first time. According to our results, at least three species currently assigned to Knodus, K. breviceps, K. gamma, and $K$. meridae, form a monophyletic group that would correspond to the "true" Knodus. Node 260 includes three species currently assigned to Knodus, but those species should be transferred to another genus according to our results. However, only a single homoplastic character state, related to maxillary dentition, supports clade 272. Additional characters and examination of more species of Knodus are needed to further support those results.

Three molecular phylogenetic studies included species of Knodus. Calcagnotto et al. (2005) analyzed only one unidentified species of the genus, which according to their results is the sister group of an unidentified species of Bryconamericus. Javonillo et al. (2010) analyzed four presumably new species of Knodus, which form a clade with Bryconadenos and Piabina. That clade is hypothesized to be the sister group of Bryconamericus diaphanus (Cope) (not analyzed herein). Oliveira et al. (2011) included only K. meridae in their analyses, which was hypothesized to be the sister group of Bryconadenos tanaothoros. It is noticeable that two of those studies found $B$. tanaothoros to be closely related to some species of Knodus. In our analyses B. tanaothoros is the sister group of a clade composed of Aulixidens eugeniae, Knodus heteresthes, and K. pectinatus (see node 260).

\section{Synapomorphy:}

1. Number of cusps of anterior maxillary teeth (139): $(0>1)$ five or more. Convergent in Hemibrycon dariensis Meek \& Hildebrand and Odontostoechus lethostigmus.

Node 233: Acrobrycon, Argopleura, Aulixidens, Bryconadenos, Diapoma, Mimagoniates, Piabarchus, Pseudocorynopoma, some species of Cyanocharax, and some species of Knodus $(9 /<1)$.

Species of Acrobrycon, Argopleura, Chrysobrycon Weitzman \& Menezes, Corynopoma Gill, Diapoma, Gephyrocharax Eigenmann, Glandulocauda Eigenmann, Hysteronotus Eigenmann, Iotabrycon Roberts, Landonia Eigenmann \& Henn, Mimagoniates, Phenacobrycon Eigenmann, Planaltina Böhlke, Pseudocorynopoma, Pterobrycon Eigenmann, Ptychocharax Weitzman, Fink, Machado-Allison \& Royero L., Scopaeocharax Weitzman \& Fink, Tyttocharax Fowler, and Xenurobrycon Myers \& Miranda-Ribeiro were included in the Glandulocaudinae (e.g.,
Weitzman \& Menezes, 1998; Weitzman, 2003) mainly by sharing the presence of a caudal-fin gland. Subsequently, Menezes \& Weitzman (2009) observed that the caudal-fin glands of Glandulocauda, Lophiobrycon, and Mimagoniates are morphologically and histologically distinct from those of the remaining genera. They considered those two types of caudal-fin glands as not homologous, divided the Glandulocaudinae, maintaining Glandulocauda Eigenmann, Lophiobrycon Castro, Ribeiro, Benine \& Melo, and Mimagoniates in this subfamily, and resurrecting the Stevardiinae to include the remaining genera bearing a caudalfin gland. Mirande (2010) proposed that the genera of Glandulocaudinae and Stevardiinae (sensu Menezes \& Weitzman, 2009) form a monophyletic group, deeply nested within a larger clade, which was redefined by him as a more encompassing Stevardiinae.

The Glandulocaudinae (sensu Weitzman \& Menezes, 1998) was proposed as related to Attonitus, Aulixidens, and Bryconamericus mennii by Mirande (2010), but that hypothesis was not corroborated by the present analysis. In our results, $B$. mennii is the sister group of a large clade including most analyzed species of the Stevardiinae, Aulixidens is related to some species of Knodus, and Attonitus is included in the node 257 with Nantis, Odontostoechus, and some species of Bryconamericus. One synapomorphy of this clade is the presence of insemination, whose presence is actually unknown in many stevardiins.

\section{List of Synapomorphies: \\ 1. Insemination (358): $(0>1)$ present.}

2. Parietal branch of supraorbital laterosensory canal (386): $(0>1)$ absent or reaching only to anterior half of parietal. Convergent in Bryconamericus cf. rubropictus, Carlastyanax aurocaudatus, and Creagrutus maracaiboensis.

Node 260: Aulixidens, Bryconadenos, Knodus heteresthes, and $K$. pectinatus $(18 /<1)$.

This clade includes a group of species currently assigned to Knodus that are not closely related to K. meridae, its type species, but instead form a clade with Aulixidens eugeniae and Bryconadenos tanaothoros. The sister group of this clade (Node 232) includes Cyanocharax obi, Piabarchus analis, and the Glandulocaudinae of Weitzman \& Menezes (1998). As noted above, one of the synapomorphies of the Node 233 (including this clade and the Node 232) is the presence of insemination, and probably all the species currently assigned to Knodus with insemination, as K. pectinatus, should be included in the Node 260. However, insemination is unknown in Aulixidens eugeniae and $K$. heteresthes. Knodus pectinatus was originally described as a species of Bryconamericus by Vari \& Siebert (1990) and later on it was tentatively transferred to Knodus (Weitzman et al., 2005) due to the presence of scales covering the anterior region of the caudal fin, a character that traditionally defined that genus. In the present analysis Knodus meridae (the type species of the genus) is 
included in the node 272 (see above) together with Bryconamericus agna, Knodus breviceps, and K. gamma. Also, Bryconamericus exodon (the type species of Bryconamericus) is included in a separate clade (see node 353). Thus, the inclusion of Knodus pectinatus in Bryconamericus or in Knodus is not supported according to our results. The four species of this clade should be transferred to Aulixidens, which is older than Bryconadenos. Interestingly, in these species, as in Knodus, scales cover the base of the caudal fin. However, this clade has low support and stability, and there are many presumably related species, as the inseminating species of Knodus (Burns \& Weitzman, 2005 ) that could be analyzed.

\section{List of synapomorphies:}

1. Contact between frontals in region anterior to frontal fontanel (21): $(0>1)$ present. Convergent in Creagrutus gephyrus.

2. Denticles on gill rakers (201): $(0>1)$ absent. Convergent in Argopleura magdalenensis and Attonitus ephimeros. Reversed in Knodus pectinatus.

Node 232: Acrobrycon, Argopleura, Diapoma, Mimagoniates, Piabarchus, Pseudocorynopoma, and Cyanocharax obi (54/9).

As mentioned before, the Glandulocaudinae sensu Weitzman \& Menezes (1998) are included in a clade with Cyanocharax obi and Piabarchus analis according to our results. The presence of insemination in the latter two species is unknown. The sister group of the Glandulocaudinae of Weitzman \& Menezes (1998) is different in relation to previous hypotheses. In the molecular study of Calcagnotto et al. (2005) a clade formed by Gephyrocharax and Mimagoniates was proposed as the sister group of the remaining Stevardiinae (as treated herein). Javonillo et al. (2010) obtained Mimagoniates as the sister group of the remaining Stevardiinae (as treated herein), among which the Glandulocaudinae (sensu Weitzman \& Menezes, 1998) are not monophyletic, with a clade composed of Corynopoma and Gephyrocharax as the sister group of the remaining stevardiins (excluding Mimagoniates). According to Javonillo et al. (2010), Diapoma is included in Cyanocharax, whereas Pseudocorynopoma is the sister group of Bryconamericus stramineus Eigenmann (in their analysis by parsimony), making the Glandulocaudinae (sensu Weitzman \& Menezes, 1998) polyphyletic. The Glandulocaudinae of Weitzman \& Menezes (1998) is also not monophyletic according to Oliveira et al. (2011), in which Tyttocharax and Xenurobrycon form the sister clade of a large group of species composed of almost all the remaining stevardiins (as treated herein). In the phylogeny presented by Mirande (2010), the Glandulocaudinae of Weitzman \& Menezes (1998) is the sister group of Bryconamericus mennii, which in the present hypothesis is included in the Node 237 (see above). This node includes Mimagoniates rheocharis, the single analyzed Glandulocaudinae sensu Menezes \& Weitzman (2009) as sister group of the Stevardiinae, as defined by them. This contrast with the results by Mirande $(2009,2010)$ in which Mimagoniates was obtained to be the sister group of Pseudocorynopoma, resulting in a paraphyletic Stevardiinae sensu Menezes \& Weitzman (2009). As in the hypotheses by Mirande $(2009,2010)$, the Glandulocaudinae and Stevardiinae of Menezes \& Weitzman (2009) are deeply nested in a more inclusive clade, which was used to support the redefinition of the Stevardiinae by Mirande (2009).

\section{List of synapomorphies:}

1. Number of branched pelvic-fin rays (258): $(1>0)$ six or less. Convergent in Carlastyanax aurocaudatus, Cyanocharax alburnus, and Knodus pectinatus.

2. Anal-fin origin (284): $(0>1)$ anterior, ventral to dorsal fin.

3. Number of branched anal-fin rays (288): $(0>1) 25$ or more.

4. Gill-derived gland on males (352): $(1>0)$ absent. Reversion of a synapomorphy of node 213 , composed of the Aphyocharacinae, Aphyoditeinae, Cheirodontinae, and Stevardiinae. Convergent in Bryconamericus cf. rubropictus, B. rubropictus, and Nantis indefessus.

Node 353: Bryconamericus exodon, Carlastyanax, Creagrutus, Microgenys, and Piabina (27/21).

This clade includes Bryconamericus exodon, the type species of the genus, as the sister species of a large clade composed of species of several genera. This relationship suggests that no species currently assigned to Bryconamericus should be maintained in this genus other than its type species, at least among those included in our analyses. Another option would be to redefine Bryconamericus as including the genera Carlastyanax, Creagrutus, Microgenys, and Piabina, but this approach would require too many nomenclatural changes. This clade is supported only by two synapomorphies that are related to premaxillary dentition. Definitions of these characters, however, are based in the assumption that the lateralmost premaxillary tooth of Creagrutus and Piabina is homologous with the anteriorly displaced tooth of the anterior premaxillary row of Bryconamericus exodon. As mentioned before, additional support for this hypothesis of homology is still necessary.

\section{List of synapomorphies:}

1. Alignment of teeth on anterior premaxillary row (124): $(0$

$>1$ ) not aligned, with one or two teeth situated anteriorly.

2. Position of lateralmost tooth of outer premaxillary row (370): $(1>0)$ anteriorly displaced relative to remaining teeth. Reversed in Creagrutus cracentis.

Node 352: Carlastyanax, Creagrutus, Microgenys, and Piabina (100/50).

A close relationship among those four genera is proposed herein for the first time, but it is in accordance with hypotheses 
presented by Mirande $(2009,2010)$. The relationships of Carlastyanax and Microgenys were not previously addressed in phylogenetic studies, and their placement in a clade that also includes Creagrutus and Piabina is one of the main results of this paper. This clade is stable across all the analyses conducted herein, and has a relatively high support. Piabina is not the sister clade of Creagrutus, but is related to species of Bryconadenos, Bryconamericus, Cyanocharax, Hypobrycon Malabarba \& Malabarba, Knodus, Odontostoechus, and/or Piabarchus according to molecular studies (Javonillo et al., 2010; Oliveira et al., 2011). Still according to those studies, Creagrutus is more basal, hypothesized to be the sister group of most species of the Stevardiinae. Those results might be related to the low sampling of genes or absence of more representative species, especially of the highly diverse Creagrutus, but could also indicate that some of the characters proposed by Vari \& Harold (2001) that support a sister-group relationship between these genera according to morphology are actually convergences.

\section{List of synapomorphies:}

1. Position of opening on neurocranium communicating with laterosensory canal of sixth infraorbital (77): $(0>1)$ in frontal. Convergent in Knodus pectinatus, Piabarchus analis, and in node 257 (see above).

2. Epiphyseal branch of supraorbital canal (84): $(1>0)$ present. Reversion of the synapomorphy 1 of the Stevardiinae (see above).

3. Margins of toothed region of maxilla (96): $(0>1)$ dorsally divergent. Reversed in Creagrutus muelleri, C. peruanus, and in node 355, composed of Creagrutus cracentis and $C$. gephyrus. Convergent in Odontostoechus lethostigmus.

4. Denticles on gill rakers (201): $(0>1)$ absent. Convergent in Argopleura magdalenensis, Attonitus ephimeros, Bryconadenos tanaothoros, and in node 260 (see above). Reversed in Carlastyanax aurocaudatus, Creagrutus atrisignum, and C. gephyrus.

5. Longitudinal position of insertion of mandibular accessory tendon (331): $(0>1)$ anterior to Meckelian cartilage. Convergent in Knodus pectinatus. Reversed in Carlastyanax aurocaudatus.

6. Number of teeth on anterior row of dentary (379): $(1>0)$ eight or fewer. Convergent in Aulixidens eugeniae, Bryconadenos tanaothoros, and Bryconamericus agna. Reversed in Carlastyanax aurocaudatus and in node 355, composed of Creagrutus cracentis and C. gephyrus.

7. Number of teeth cusps in anterior row of dentary (380): (1 $>0$ ) three or fewer. Reversed in Carlastyanax aurocaudatus and in node 355, composed of Creagrutus cracentis and $C$. gephyrus. Convergent in Knodus pectinatus and Mimagoniates rheocharis.
Node 351: Carlastyanax, Creagrutus, and Piabina (100/64).

A sister-group relationship between Creagrutus and Piabina was proposed by Vari \& Harold (2001) and Mirande $(2009,2010)$ but these authors did not include Carlastyanax in their analysis. As noted before, Piabina is not closely related to Creagrutus according to molecular studies. Javonillo et al. (2010) hypothesized Creagrutus as the sister group of a large clade including Piabina, in an even more encompassing clade that also includes Bryconamericus diaphanus, an unidentified species of Bryconadenos, and four undescribed species of Knodus. Oliveira et al. (2011) proposed a phylogenetic hypothesis which is similar to that of Javonillo et al. (2010), where Creagrutus is the sister group of a large clade composed of Bryconadenos, Bryconamericus exodon (the type species of the genus), Ceratobranchia Eigenmann, Cyanocharax, Hypobrycon, Knodus, Odontostoechus, Piabarchus, and Piabina. In that clade, Piabina is the sister group of Piabarchus. The close relationship between Creagrutus and Piabina, supported by morphology but so far not supported by molecular sequences, remains as an interesting phylogenetic issue that should be explored in future studies.

\section{List of synapomorphies:}

1. Ventral projection of mesethmoid spine, forming a keel between premaxillae (26): $(0>1)$ present. Reversed in node 355, composed of Creagrutus cracentis and C. gephyrus.

2. Anterior confluence of ventral diverging lamellae with nasal septum of mesethmoid (31): $(1>0)$ absent, or confluent near anterior end of nasal septum.

3. Number of rows of premaxillary teeth (123): $(0>1)$ three. Reversed in Creagrutus cracentis.

4. Relative length of palatine (172): $(1>0)$ approximately half length of ectopterygoid or less than that. Convergent in Knodus pectinatus. Reversed in Creagrutus anary and $C$. taphorni.

5. Rows of gill rakers on second ceratobranchial (193): (1> 0 ) one. Reversal of the synapomorphy 1 of node 236 (see above). Convergent in node 230, composed of the Glandulocaudinae (sensu Weitzman \& Menezes, 1998). Reversed in Creagrutus cracentis and C. maracaiboensis.

6. Premaxillary dentition (368): $(0>1)$ with a recognizable triad of larger teeth with rounded base. Reversed in node 355, composed of Creagrutus cracentis and C. gephyrus.

7. Attachment of maxilla with premaxilla (376): $(0>1)$ a strong ligament attached to a greatly bifurcated premaxilla.

Node 350: Carlastyanax and Creagrutus (100/98).

A close relationship between Carlastyanax and Creagrutus is herein proposed for the first time, and is considered as the main result of our analyses. According to 
this relationship, Carlastyanax is revalidated and proposed as a member of the Stevardiinae. The sister group relationship between Carlastyanax and Creagrutus is stable in all the explored conditions in different analyses, and is also well supported according to resampling measures. Some synapomorphies relating those genera, especially the presence of a ligament between the ascending process of the maxilla and the dorsal margin of the alveolar premaxillary ramus, are unique to this clade or highly unusual among the Characidae.

List of synapomorphies:

1. Longitudinal ridge in quadrate bordering adductor mandibulae muscle ventrally and, to some extent, laterally (152): $(0>1)$ present.

2. Teeth on third pharyngobranchial (206): $(0>1)$ absent.

3. Flexion on maxilla posterior to alveolar premaxillary arm (372): $(0>1)$ pronounced.

4. Form and attachment of primordial ligament (373): $(0>1)$ round in cross section and attached to distal half of maxillary lamella.

5. Ligament between middle length of ascending maxillary process and premaxilla (378): $(0>1)$ present.

6. Posterodorsal portion of anguloarticular (382): $(1>0)$ vertical. Convergent in Knodus pectinatus. Reversed in node 355, composed of Creagrutus cracentis and C. gephyrus.

7. Posterior region of mesopterygoid (383): $(0>1)$ separate from metapterygoid. Reversed in Creagrutus gephyrus. Convergent in Knodus pectinatus.

\section{Autapomorphies of Carlastyanax aurocaudatus:}

1. Length of supraoccipital spine (53): $(1>0)$ extends posteriorly to at least middle length of neural complex. Convergent in Argopleura magdalenensis and Creagrutus meridionalis.

2. Fourth infraorbital (66): $(0>1)$ absent or reduced and bordered by third and fifth infraorbitals.

3. Position of opening on cranium that connects with infraorbital canal of sixth infraorbital (78): $(0>1)$ distinctly anterior to vertical semicircular canal. Convergent in Creagrutus gephyrus, C. peruanus, and Microgenys minuta.

4. Mandibular sensory canal on dentary (79): $(0>1)$ reduced or absent.

5. Canal of lateral line on caudal-fin membrane (92): $(1>0)$ absent. Convergent in Cyanocharax obi, Diapoma speculiferum Cope, and Nantis indefessus.
6. Ventral margin of horizontal process of anguloarticular (109): $(1>0)$ posteroventrally angled relative to mandibular laterosensory canal. Convergent in Knodus pectinatus, Microgenys minuta, node 256, composed of Attonitus and Nantis, and node 358, composed of Creagrutus muelleri and C. ouranonastes.

7. Bony lamella dorsal to fourth basibranchial (185): $(0>1)$ absent. Convergent in Creagrutus gephyrus, C. taphorni, Knodus heteresthes, Mimagoniates rheocharis, and Piabarchus analis.

8. Denticles on gill rakers (201): $(1>0)$ present. Reversal of the synapomorphy 4 of node 352 (see remarks above). Convergent in Creagrutus atrisignum and C. gephyrus.

9. Rows of gill rakers on first epibranchial (203): $(1>0)$ one. Convergent in Creagrutus atrisignum.

10. Development of transverse process of neural arch of third vertebra (219): $(0>1)$ well developed and extending beyond anterior margin of tripus. Convergent in Cyanocharax alburnus and Knodus pectinatus.

11. Posterior margin of cleithrum (234): $(1>0)$ without concavity ventral to first postcleithrum.

12. Position of ventral end of posttemporal (253): $(0>1)$ posterior to lateral margin of epioccipital. Convergent in Creagrutus atrisignum.

13. Number of branched pelvic-fin rays (258): $(1>0)$ six or less. Convergent in Cyanocharax alburnus, Knodus pectinatus, and node 232 [composed of Cyanocharax obi, Piabarchus analis, and the Glandulocaudinae of Weitzman \& Menezes (1998)].

14. Longitudinal position of insertion of mandibular accessory tendon (331): $(1>0)$ ventral to Meckelian cartilage. Reversal of synapomorphy 4 of node 352 (see remarks above).

15. Form of third dentary tooth (367): $(0>1)$ strongly decurved posteriorly.

16. Number of teeth on anterior row of dentary (379): $(0>1)$ ten or more. Reversal of synapomorphy 5 of node 352 . Convergent in node 355 (composed of Creagrutus cracentis and C. gephyrus).

17. Number of cusps of anterior dentary teeth (380): $(0>1)$ five or more. Reversal of synapomorphy 6 of node 352 (see remarks above). Convergent in node 355 (composed of Creagrutus cracentis and C. gephyrus).

18. Parietal branch of supraorbital laterosensory canal (386): $(0>1)$ absent or reaching only to anterior half of parietal. 
Convergent in Bryconamericus cf. rubropictus and Creagrutus maracaiboensis.

Node 349: Creagrutus (100/93).

The monophyly of Creagrutus was proposed by Vari \& Harold (2001) based on 11 morphological synapomorphies. Most of the synapomorphies obtained herein for Creagrutus were previously proposed by those authors, and there is little doubt about the monophyly of this genus. Among the molecular phylogenies of the Characidae, only Javonillo et al. (2010) analyzed more than one species of Creagrutus. In their phylogeny, Creagrutus ignotus Vari \& Harold and Creagrutus sp. form a monophyletic unit which is the sister group of a large clade composed of species of Bryconadenos, Bryconamericus, Cyanocharax, Diapoma, Hypobrycon, Knodus, Odontostoechus, and Piabina.

\section{List of synapomorphies:}

1. Shape of dentigerous plate of fifth ceratobranchial (204): $(1>0)$ rounded, with posterior notch. Reversed in Creagrutus maracaiboensis.

2. Number of unbranched anal-fin rays (285): $(1>0)$ three or fewer. Convergent in Microgenys minuta.

3. Number of ventral procurrent caudal-fin rays (302): ( 0 > 1) 12 or more. Reversed in Creagrutus cracentis and $C$. maracaiboensis.

4. Anterior process of maxilla (371): $(0>1)$ as thick as posterior region. Convergent in Aulixidens eugeniae. Reversed in Creagrutus cracentis.

\section{Ligament between distal tip of ascending maxillary process} and premaxilla (377): $(0>1)$ present.

6. Expansion of dentary lateral to anguloarticular (381): (0> 1) closer to articular socket than to Meckelian cartilage.

7. Medial dorsal ridge of quadrate (384): $(0>1)$ present, laterally covering the symplectic.

8. Cartilage-filled region anterior to scapular foramen (387): $(0>1)$ much reduced by expansions of coracoid and cleithrum. Convergent in Attonitus ephimeros and node 231 [composed of Cyanocharax obi and Glandulocaudinae sensu Weitzman \& Menezes (1998)].

\section{Results of the Extended Matrix}

The most stable results in the Extended Matrix, including all the species of Creagrutus coded from literature, were obtained in the $10^{\text {th }}$ and $11^{\text {th }}$ values of $\mathrm{K}(=12.59-13.88)$. The consensus of the most parsimonious trees obtained in these concavities is much similar to the one obtained from the Examined Matrix, except by the position of the species of
Knodus and the internal relationships of Creagrutus (Fig. 8). In this hypothesis the species of Knodus form a monophyletic group, with $K$. gamma as the sister group of the remaining species of the genus. However, this clade has low stability and support, and therefore this hypothesis should be further tested with the addition of a higher number of species and characters. Within Creagrutus, a clade composed of $C$. maracaiboensis, C. muelleri, C. nigrostigmatus, $C$. ouranonastes, and $C$. peruanus is the sister group of another composed of $C$. affinis Steindachner, C. crenatus Vari \& Harold, C. hildebrandi Schultz, C. lepidus, C. manu Vari \& Harold, C. melasma Vari, Harold \& Taphorn, and C. pearsoni Mahnert \& Géry, and a polytomy including the remaining species of the genus, of which some are grouped in small clades (Fig. 8). Those relationships are similar to the ones proposed by Vari \& Harold (2001). Additional resolution in this large clade relative to Vari \& Harold (2001) is possibly attributed to the use of implied weighting instead of equal weighting. The large polytomy obtained is almost exclusively due to the lack of unambiguous synapomorphies for most of the internal nodes of the genus, rather than to characterstates conflicts. The resolution of the relationships within Creagrutus is beyond the scope of this paper and the intention of this last analysis is only to corroborate the position of Carlastyanax when all the currently available information is analyzed in a single matrix.

\section{Discussion}

Eigenmann (1913) placed the species now recognized as Carlastyanax aurocaudatus in Astyanax in spite of the presence of four teeth in the posterior premaxillary row. Eigenmann later considered that this species should be separated from Astyanax and included in a different genus, based on its coloration, the form of the third infraorbital, and the form of the third dentary tooth (Eigenmann, 1927). However, Eigenmann did not mention the possession of just four teeth in the posterior premaxillary row as something unusual for Astyanax or a species thought to be related to that genus. The creation of Carlastyanax by Géry (1972) was not well supported because it was based on the morphological divergence of $A$. aurocaudatus and not on the supposed relationships of this species. The degree of morphological difference or similarity in itself is not a reason to take nomenclatural decisions. The single important question is if one or more characters indicate (at least tentatively) phylogenetic relationships between taxa. Astyanax aurocaudatus has all the diagnostic characters of Bryconamericus except the reduced third infraorbital (Fig. 5 ), although this feature is actually present in some species of the genus (e.g., Bryconamericus rubropictus). The hooked third dentary tooth could also have been considered as an autapomorphy of A. aurocaudatus, and as such, irrelevant to the relationships of the species. However, the creation of Carlastyanax to include A. aurocaudatus by Géry (1972), in the absence of a phylogenetic hypothesis 


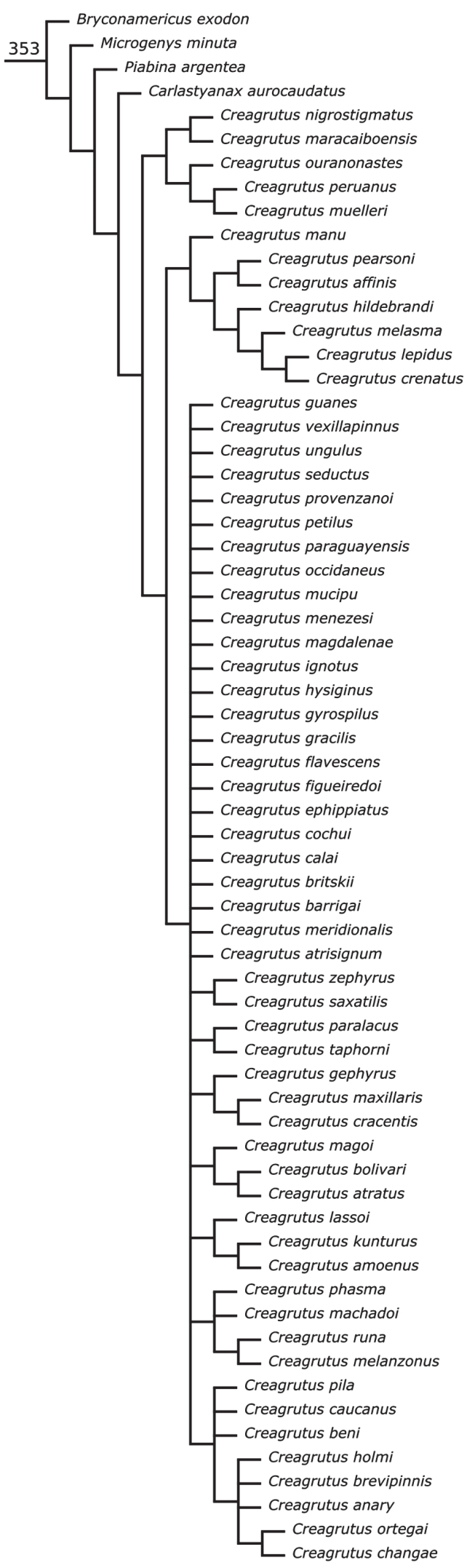

Fig. 8. Detail of the cladogram obtained with the Extended Matrix. Clade 353 corresponds to the clade with the same number in Fig. 7. for the Characidae, provided a generic name that in the present analysis is supported as valid.

Ruiz-C. \& Román-Valencia (2006) considered that the characters supporting the creation of Carlastyanax were "incorrect observations", and thus synonymized Carlastyanax with Astyanax. Those authors reasoned that, as some species of Bryconamericus have five teeth on the posterior premaxillary row (they cited Román-Valencia, 2003), that condition could not be diagnostic of Astyanax (Ruiz-C. \& Román-Valencia, 2006: 61). We interpret that their reasoning was that if the presence of five teeth on the posterior premaxillary row is unreliable as a "generic" character state, the same occurs with the presence of four teeth and, thus, the presence of only four teeth in Carlastyanax is irrelevant to its generic assignment. That reasoning is obviously flawed.

Ruiz-C. \& Román-Valencia (2006: 61) also stated that the form of the third dentary tooth could not be considered as a diagnostic character of Carlastyanax, because both Astyanax brachypterygium Bertaco \& Malabarba and A. cremnobates Bertaco \& Malabarba have curved dentary teeth (they cited Bertaco \& Malabarba, 2001). However, they did not explicitly stated that Carlastyanax and those two species of Astyanax might be related, a situation that would justify both the inclusion of Carlastyanax in Astyanax and the non-validity of the third dentary teeth as a diagnostic feature of Carlastyanax. In addition, a particularly curved third dentary tooth in those species of Astyanax was not mentioned by Bertaco \& Malabarba (2001) or shown in their figures. Although we did not analyze specimens of $A$. brachypterygium, examined specimens of $A$. cremnobates do not have that feature. Bertaco \& Malabarba (2001: 226, 229) mentioned that "all cusp tips" of the dentary teeth of those species of Astyanax are "slightly curved posteriorly towards inside of mouth". This condition is commonly found in the characids and is actually quite distinct from the condition present on the third dentary tooth of $C$. aurocaudatus. In our analyses, this condition is an autapomorphy of Carlastyanax aurocaudatus, diagnostic for the genus, but irrelevant for the generic assignment of this species.

Ruiz-C. \& Román-Valencia (2006) also discussed some similarities of Carlastyanax aurocaudatus with Astyanax mexicanus (De Filippi), the type species of Astyanax, such as the absence of teeth in the palatine, ectopterygoid, and mesopterygoid. However, those authors did not mention that these features are also shared by most characids. They also said that the putative close relationship of Carlastyanax with some species of Hemibrycon, proposed by Géry (1972), is not supported because they have different "coloration models" ("modelos de coloración", in the original) and "ecological aspects". Regardless of the validity of those remarks, most systematists would not find those attributes as relevant in a taxonomic discussion. Also, as mentioned above, differences themselves are not indicators of phylogenetic relationships and should not be taken into 
consideration for generic assignments.

Several inconsistencies in the osteological description of Carlastyanax aurocaudatus presented by Ruiz-C. \& Román-Valencia (2006) were also detected. According to those authors, the supraorbital bone is present in $C$. aurocaudatus as a long and narrow structure joined laterally to the frontal. However, the supraorbital is absent in the specimens of $C$. aurocaudatus we examined, a condition previously noted by Bertaco et al. (2007: 255). We agree with Bertaco et al. (2007: 255) that the "supraorbital" of Ruiz-C. \& Román-Valencia (2006) in C. aurocaudatus and some species of Hemibrycon is actually the lateralmost portion of the frontal. Mirande $(2009,2010)$ found that the supraorbital bone is absent in the Stevardiinae and only present in basal members of the clade assigned to Characidae (e.g., Acestrorhynchinae, Agoniatinae, Bryconinae, Cynodontinae, and Salmininae). Ruiz-C. \& Román-Valencia (2006) also reported the presence of a rhinosphenoid "in cartilaginous state" in C. aurocaudatus. In the adult specimens examined by us the rhinosphenoid is absent, and only the ethmoid cartilage is present. Ruiz-C. \& RománValencia (2006: 57 and figs. 11 and 12) also provided wrong descriptions of the position of the posttemporal, supracleithrum, and cleithrum, including their figures. They stated that in C. aurocaudatus the posttemporal reaches ventrally to the cleithrum, while actually it reaches only to the supracleithrum, as is usual in the Characidae. Ruiz-C. \& Román-Valencia (2006) described the supracleithrum as a large bone that is joined to the dorsal margin of cleithrum, but they also stated that the mesocoracoid (spelled as "mesocaracoid" in their paper) articulates with the medial surface of the supracleithrum, when in C. aurocaudatus and in all the remaining examined characids the mesocoracoid articulates with the cleithrum.

Although a comprehensive phylogenetic analysis of the Characidae was not available in the time that Ruiz-C. \& RománValencia (2006) transferred Carlastyanax aurocaudatus to Astyanax, there was a sort of "agreement" about the monophyly of a clade more or less equivalent to the "clade A" proposed by Malabarba \& Weitzman (2003). That clade, later redefined as the Stevardiinae by Mirande (2009, 2010), was proposed based on two putative synapomorphies: the presence of eight branched dorsal-fin rays ( $v s$. nine in most other characids) and the presence of four teeth on the posterior premaxillary row ( $v s$. five or more teeth in most other characids with two rows of premaxillary teeth), which are present in Carlastyanax aurocaudatus. The Stevardiinae of Mirande (2009, 2010) does not include Astyanax, which has five premaxillary teeth in the posterior row and nine branched dorsal-fin rays. Thus, even without considering the published phylogenies and concluding that Carlastyanax is not valid for some reason, this genus has a characters combination that suggested its inclusion in the Stevardiinae and this, in turn, precludes its synonymy with Astyanax.

The position of Carlastyanax as the sister group of Creagrutus was not previously explicitly proposed. Vari \&
Siebert (1990) noted that Knodus pectinatus (referred to in their paper as Bryconamericus pectinatus) shares several features with Carlastyanax aurocaudatus, and therefore a possible relationship between those two species was proposed. Vari \& Harold (2001) hypothesized that Piabina is the sister group of Creagrutus, but they did not examine Carlastyanax. According to our results, Piabina is actually the sister group of a clade composed of Carlastyanax and Creagrutus.

Comparative material. Examined specimens additional to Mirande (2010) and Mirande et al. (2011). Acrobrycon tarijae: CI-FML 3880, 5 (2 C\&S ), río Mandolo, Capitán Cáceres, Monteros, Tucumán Argentina. Argopleura magdalenensis: CI-FML 5879 (Ex CZUT-IC 1428), 2 (1 C\&S), Tuluní creek, Magdalena, Tolima, Colombia. CI-FML 5016, 4 (2 C\&S), río La Vieja, Alejandría, Quimbaya, Quindío, Colombia. Bryconadenos tanaothoros: MCP 30516, 106 (5 C\&S), Corrego Tatú, Cláudia, Mato Grosso, Brazil. Bryconamericus iheringii: CI-FML 5880, 4 (C\&S), stream10 km to the bridge in the road 2, Coronel Vidal, Buenos Aires, Argentina. Carlastyanax aurocaudatus: CI-FML 5015, 15 (2 C\&S), La Siria Creek, río la Vieja basin, upper Cauca, Colombia. Creagrutus atrisignum: MCP 15929, 49 (6 C\&S), Ribeirão do Engenho, Niquelândia, Goiás, Brazil. Creagrutus cracentis: USNM 353862, 2 (1 C\&S), paratypes, rio Tapajós, Itaiuba, Pará, Brazil. Creagrutus gephyrus: USNM 324461, 4 (1 C\&S), río Napo, Coca, Napo, Ecuador; USNM 340953, 6 (1 C\&S), río Napo, Coca, Napo, Ecuador. Creagrutus maracaiboensis: USNM 121532, 41 (1 C\&S), paratypes, río Negro, Lago Maracaibo basin, Venezuela; USNM 357791, 10 (2 C\&S), río Negro, Zulia, Venezuela. Creagrutus meridionalis: MCP 10677, 24 (4 C\&S), stream near Salgadeiro, Estrada Cuiabá-Chapada dos Guimarães, Chapada dos Guimarães, Mato Grosso, Brazil. Creagrutus muelleri: USNM 340984, 10 (2 C\&S), río Pastaza, Pastaza, Ecuador; USNM 340983, 4 (1 C\&S), río Zamora, Zamora-Chincipe, Ecuador. Creagrutus ouranonastes: USNM 340988, 4 (1 C\&S), paratypes, río Chalhuanca, Aymaraes, Apurimac, Perú. Creagrutus peruanus: USNM 340981, 7 (2 C\&S), río Mijandri, Junin, Peru; USNM 340979, 8 (2 C\&S), río Chanchamayo, Mijandri, Chanchamayo, Junin, Peru. Cyanocharax obi: CI-FML 3892, 4 (3 C\&S), Moreno stream Aristóbulo del Valle, Misiones, Argentina. Hyphessobrycon megalopterus: CI-FML 5013, $1(\mathrm{C} \& \mathrm{~S})$ aquarium specimen, Knodus heteresthes: MHNG 2184.051, 45 (3 C\&S) Gaa Kaba, Maroni, French Guiana, Knodus meridae: MCP 44038, Culebra, near Puerto Ayacucho, Amazonas, Venezuela. Knodus pectinatus: USNM 303441, 5 (1 C\&S), río Manu, Pakitsa, Manu, Madre de Dios, Peru; USNM 303442, 8 (1 C\&S), Pakitsa, río Manu drainage, Manu, Madre de Dios, Peru. Microgenys minuta: CI-FML 5021, 2 (1 C\&S) río La Vieja, Alejandría, Quimbaya, Quindío, Colombia. Piabarchus analis: MCP 15571, stream near Estrada Barra do Bugres, Cáceres, Mato Grosso, Brazil. Pseudocorynopoma doriae: AI 309, 4 (2 C\&S), río Uruguay, Entre Ríos, Argentina.

\section{Acknowledgments}

The authors thank Luiz Malabarba (UFRGS) and Richard Vari (USNM) for encouragement and support to publish this study. We thank Cristina Butí (FML), Carlos Lucena (PUCRS), Sandra Raredon and Jeff Williams (USNM), Sonia Fisch-Müller (MHNG), Mark Sabaj-Perez and John Lundberg (ANSP), César Román-Valencia (IUQ), and Francisco VillaNavarro (CZUT-IC) for loan or exchange of material. We also 
thank Mercedes Azpelicueta (MLP) and Pablo Goloboff (IML) for permanent support. This manuscript was almost completely built under a Linux platform. We thank ArchLinux, Manjaro, GIMP, and LibreOffice communities. We are also thankful to the Smithsonian Institution for logistics and funding to F. C. Jerep. Study partially funded by Fundación Miguel Lillo, CONICET (PIP-11420110100301 to J. M. Mirande), Fundación para la Promoción de la Investigación y la Tecnología, Banco de la República (FPIT 2814 to J. A. Vanegas Rios and J. M. Mirande), and FONCyT (PICT-20081201 to J. M. Mirande). TNT was provided free by the Willi Hennig Society.

\section{Literature Cited}

Baicere-Silva, C. M., R. C. Benine \& I. Quagio-Grassioto. 2011. Markiana nigripinnis (Perugia, 1891) as a putative member of the subfamily Stevardiinae (Characiformes: Characidae): spermatic evidence. Neotropical Ichthyology, 9: 371-376.

Bertaco, V. A. \& L. R. Malabarba. 2001. Description of two new species of Astyanax (Teleostei: Characidae) from headwater streams of Southern Brazil, with comments on the $A$. scabripinnis species complex. Ichthyological Exploration of Freshwaters, 12: 221-234.

Bertaco, V. A., L. R. Malabarba \& H. Ortega. 2007. A new species of Hemibrycon (Teleostei: Characiformes: Characidae) from the río Ucayali drainage, Sierra del Divisor, Peru. Neotropical Ichthyology, 5: 251-257.

Burns, J. R. \& S. H. Weitzman. 2005. Insemination in ostariophysan fishes. Pp. 107-134. In: Uribe, M. C. \& H. J. Grier (Eds.). Viviparous Fishes. Florida, New Life Publishers.

Calcagnotto, D., S. A. Schaefer \& R. DeSalle. 2005. Relationships among characiform fishes inferred from analysis of nuclear and mitochondrial gene sequences. Molecular Phylogenetics and Evolution, 36: 135-153.

Casciotta, J., A. Almirón, L. Piálek \& O. Øíèn. 2012. Cyanocharax $o b i$, a new species (Characiformes: Characidae) and the first record of the genus from tributaries of the río Paraná basin, Argentina. Zootaxa, 3391: 39-51.

Di Dario, F. 2004. Homology between the recessus lateralis and cephalic sensory canals, with the proposition of additional synapomorphies for the Clupeiformes and the Clupeoidei. Zoological Journal of the Linnean Society, 141: 257-270.

Eigenmann, C. H. 1913. Some results from an ichthyological reconnaissance of Colombia, South America. Part II. New genera and new species of fishes. Indiana University Studies, 18: $22-30$.

Eigenmann, C. H. 1914. Some results from studies of South American fishes. II. The Glandulocaudinae (a new subfamily of characid fishes with innate potentialities for sexual dimorphism. Indiana University Studies, 20: 32-42.

Eigenmann, C. H. 1927. The American Characidae. Memoirs of the Museum of Comparative Zoology, 43: 311-428.

Farris, J. S. 1989. The retention index and the rescaled consistency index. Cladistics, 5: 417-419.

Ferreira, K. M., N. A. Menezes \& I. Quagio-Grassioto. 2011. A new genus and two new species of Stevardiinae (Characiformes: Characidae) with a hypothesis on their relationships based on morphological and histological data. Neotropical Ichthyology, 9: 281-298.
Géry, J. 1972. Contribution à l'étude des poissons characoïdes de l'Équateur, avec une révision du genre Pseudochalceus et la description d'une nouveaux genre endémique du Rio Cauca en Colombie. Acta Humboldtiana, 2: 1-110.

Géry, J. 1977. Characoids of the World. Neptune City, TFH Publications.

Goloboff, P. A. 1993. Estimating character weights during tree search. Cladistics, 9: 83-91.

Goloboff, P. A. 1999. Analyzing large data sets in reasonable times: Solutions for composite optima. Cladistics, 15: 415-428.

Goloboff, P .A. 2008. Calculating SPR distances between trees. Cladistics, 24: 591-597.

Goloboff, P. A. 2013. Extended implied weighting. Cladistics, DOI: 10.1111/cla.12047.

Goloboff, P. A., J. M. Carpenter, J. S. Arias \& D. R. Miranda Esquivel. 2008b. Weighting against homoplasy improves phylogenetic analysis of morphological data sets. Cladistics, 24: 576-583.

Goloboff, P. A., J. S. Farris, M. Källersjö, B. Oxelman, M. J. Ramírez \& C. A. Szumik. 2003. Improvements to resampling measures of group support. Cladistics, 19: 324-332.

Goloboff, P. A., J. S. Farris \& K. C. Nixon. 2008a. TNT, a free program for phylogenetic analysis. Cladistics, 24: 774-786.

Javonillo, R., L. R. Malabarba, S. H. Weitzman \& J. R. Burns. 2010. Relationships among major lineages of characid fishes (Teleostei: Ostariophysi: Characiformes), based on molecular sequence data. Molecular Phylogenetics and Evolution, 54: 498-511.

Malabarba, L. R. \& S. H. Weitzman. 2003. Description of a new genus with six species from southern Brazil, Uruguay and Argentina, with a discussion of a putative characid clade (Teleostei: Characiformes: Characidae). Comunicações do Museu de Ciências e Tecnologia da PUCRS, Série Zoologia, 16: 67-151.

McDowall, R. M. 1999. Caudal skeleton in Galaxias and allied genera (Teleostei: Galaxiidae). Copeia, 1999: 932-939.

Menezes, N. A. \& S. H. Weitzman. 2009. Systematics of the Neotropical fish subfamily Glandulocaudinae (Teleostei: Characiformes: Characidae). Neotropical Ichthyology, 7: 295-370.

Mirande, J. M. 2009. Weighted parsimony phylogeny of the family Characidae (Teleostei: Characiformes). Cladistics, 25: 574-613.

Mirande, J. M. 2010. Phylogeny of the family Characidae (Teleostei: Characiformes): from characters to taxonomy. Neotropical Ichthyology, 8: 385-568.

Mirande, J. M. 2012. Primer registro de Nantis indefessus (Characidae: Stevardiinae) en la cuenca del río Juramento, Salta, Argentina. Acta zoológica Lilloana, 56: 153-158.

Mirande, J. M., G. Aguilera \& M. M. Azpelicueta. 2011. A threatened new species of Oligosarcus and its phylogenetic relationships, with comments on Astyanacinus (Teleostei: Characidae). Zootaxa, 2994: 1-20.

Nixon, K. C. \& J. M. Carpenter. 2012. On homology. Cladistics, 28: $160-169$

Oliveira, C., G. S. Avelino, K. T. Abe, T. C. Mariguela, R. C. Benine, G. Ortí, R. P. Vari \& R. M. C. Castro. 2011. Phylogenetic relationships within the speciose family Characidae (Teleostei: Ostariophysi: Characiformes) based on multilocus analysis and extensive ingroup sampling. BMC Evolutionary Biology, 11: 275.

Román-Valencia, C. 2003. Three new species of Bryconamericus (Teleostei: Characidae) from Venezuela. Dahlia, 6: 1-15. 
Román Valencia, C. \& R. I. Ruiz-C. 2005. Diet and reproduction aspects of Astyanax aurocaudatus (Teleostei: Characidae) from the upper part of the río Cauca, Colombia. Dahlia, 8: 9-17.

Ruiz-C. R. I. \& C. Román Valencia. 2006. Osteología de Astyanax aurocaudatus Eigenmann, 1913 (Pisces, Characidae), con notas sobre la validez de Carlastyanax Géry, 1972. Animal Biodiversity and Conservation, 29.1: 49-64.

Taylor, W. R. \& G. C. van Dyke. 1985. Revised procedures for staining and clearing small fishes and other vertebrates for bone and cartilage study. Cybium, 9: 107-119.

Torres-Mejia, M. \& R. P. Vari. 2005. New species of Creagrutus (Teleostei: Ostariophysi: Characiformes) from the río Magdalena basin, Colombia. Copeia, 2005: 812-817.

Vari, R. P. \& A. S. Harold. 2001. Phylogenetic study of the Neotropical fish genera Creagrutus Günther and Piabina Reinhardt (Teleostei: Characiformes: Characidae), with a revision of the cis-Andean species. Smithsonian Contributions to Zoology, 613: 1-239.

Vari, R. P. \& D. J. Siebert. 1990. A new, unusually sexually dimorphic species of Bryconamericus (Pisces: Ostariophysi: Characidae) from the Peruvian Amazon. Proceedings of the Biological Society of Washington, 103: 516-524.

Weiss, F. E., L. R. Malabarba \& M. C. Malabarba. 2012. Phylogenetic relationships of Paleotetra, a new characiform fish (Ostariophysi) with two new species from the EoceneOligocene of south-eastern Brazil. Journal of Systematic Palaeontology, 10: 73-86.

Weitzman, S. H. 2003. Subfamily Glandulocaudinae. Pp. 222230. In: Reis, R. E., S. O. Kullander \& C. J. Ferraris Jr. (Eds.) Check List of the Freshwater Fishes of South and Central America. Porto Alegre, Edipucrs.
Weitzman, S. H. \& N. A. Menezes. 1998. Relationships of the tribes and genera of the Glandulocaudinae (Ostariophysi, Characiformes, Characidae) with the description of a new genus, Chrysobrycon. Pp. 171-192. In: Malabarba, L. R., R. E. Reis, R. P. Vari, Z. M. S. Lucena \& C. A. S. Lucena (Eds.). Phylogeny and Classification of Neotropical Fishes. Porto Alegre, Edipucrs.

Weitzman, S. H., N. A. Menezes, H.-G. Evers \& J. R. Burns. 2005. Putative relationships among inseminating and externally fertilizing characids, with a description of a new genus and species of Brazilian inseminating fish bearing an anal-fin gland in males (Characiformes: Characidae). Neotropical Ichthyology, 30: 329-360.

Zanata, A. M. \& R. P. Vari. 2005. The family Alestidae (Ostariophysi, Characiformes): A phylogenetic analysis of a trans-Atlantic clade. Zoological Journal of the Linnean Society, 145: 1-144.

Submitted October 16, 2012 Accepted June 4, 2013 by Fabio Di Dario Published December 27, 2013

Supplementary files available at www.scielo.br/ni:

Supplementary File 1: Script used for tree searches. Supplementary File 2: List of characters in phylogenetic analyses. Supplementary File 3: Data set. 